\title{
Impact of Green Entrepreneurship Orientation on Environmental Performance: The Natural Resource- Based View Perspective
}

Lahcene Makhloufi ( $\square$ lahcenma85@gmail.com )

Universiti Utara Malaysia https://orcid.org/0000-0001-6419-6928

\section{Tang Meirun}

Guizhou University

\section{Fateh Belaid}

Lille Catholic University: Universite Catholique de Lille

Noorulsadiqin Azbiya Yaacob

Universiti Utara Malaysia

\section{Research Article}

Keywords: Green entrepreneurship orientation, Green innovation performance, Environmental performance, Green absorptive capacity, the natural resource-based view.

Posted Date: February 9th, 2021

DOl: https://doi.org/10.21203/rs.3.rs-166004/v1

License: (9) (1) This work is licensed under a Creative Commons Attribution 4.0 International License. Read Full License 


\section{Abstract}

Environmental sustainability is the primary task of environmental entrepreneurship by critically handling increased institutional, customer, and environmental pressures. Green entrepreneurship orientation (GEO) seeks to harmonize their relationships with the external environment to foster the impact of green innovation performance (GIP) on environmental performance (EP). Drawing upon the natural resourcebased view, the study examines the effect of green entrepreneurship orientation on GIP and EP. Additionally, the moderating effect of managerial environmental concerns (MEC) on this relationship is also inspected. The results revealed that green absorptive capacity (GAC), environmental cooperation (EC), and MEC significantly affect GEO. Furthermore, GEO positively influenced GIP and EP. Indeed, GEO partially mediates GAC, EC, and managerial concern's relationship on green innovation and EP. Additionally, MEC significantly moderates the relationship between GEO and EP. Firms GEO should adequately enhance green practices performance and environmental performance to accommodate their external environment relationships. Theoretical and practical implications were also presented.

\section{Introduction}

Drawing upon the Natural Resource-Based View (NRBV) lens, in the highly uncertain environment, firms search to capture business opportunities that led to create sustainable competitive advantages and improve environmental performance (Hart, 1995; Rehman, Kraus, Shah, Khanin, \& Mahto, 2020). Green entrepreneurship orientation (GEO) mainly emphasized those environmental activities by capturing ecofriendly opportunities while pursuing their businesses (Jiang, Chai, Shao, \& Feng, 2018). Thus, this study viewed GEO as dynamic alertness to fit external environmental responsibilities. These responsibilities are usually based on three distinct criteria: pollution reduction, product stewardship, and sustainable development (Hart \& Dowell, 2011; Rehman et al., 2020).

Advancing the NRBV lens, this study argued that GEO is a strategic resource embedded within and between the core organizational culture and a dynamic capability that fosters firms' abilities to sense and capture opportunities and maintain their environmental activities. This can be succeeded by (1) facilitating green practices within core environmental activities; (2) using cooperation based on environmental responsibilities to motivate GEO proactive strategies that aim at improving green environmental activities; (3) acquiring and leveraging green knowledge within green activities; (4) applying green organizational knowledge and external environmental cooperation to enhance environmental performance.

GEO is a new promise seeking to improve both sides of an organization financially and environmentally (Jiang et al., 2018). Since the core focus of GEO is to address environmental issues by supplying ecofriendly products (Guo, Wang, \& Chen, 2020). Hence, GEO's primary responsibility is to respond to external ecological parties such as customer environmental awareness, governmental and societal regulations, economic and environmental concerns (Chen \& Chang, 2013) by developing green practices (Kraus, Rehman, \& García, 2020). GEO also ensures and prioritizes improving the green workplace environment to 
reduce hazardous waste, increase job satisfaction and employee performance (Bangwal \& Tiwari, 2019). Hence, the more GEO exploits environmental business opportunities, the greater the green practice's capabilities, resulting in fostering environmental performance (Ullah \& Qaiser Danish, 2020). Examining whether GEO reflects the responsibility to respond to environmental activities by leveraging green practices is theoretically critical and empirically is the first research responding to test the NRBV theory's promise, more particularly if environmental conditions differ and wide.

Besides, green innovation performance (GIP) plays a significant part in resolving these pressures to promote GEO. These goals can succeed through leveraging green practices that consist of clean technologies, ecofriendly products, new advanced systems, green skills, a green workplace environment, and resource efficiencies (Guo et al., 2020; Jiang et al., 2018). Green technology innovation is the primary source for advancing the industry and fostering eco-systems (Raza \& Murad, 2014). GIP is the intermediary process and practices used by firms to enhance business growth and control environmental degradation (Rehman et al., 2020). The corporation's green image reflects the high responsiveness and responsibilities to ecological problems (Tang, Walsh, Lerner, Fitza, \& Li, 2018). Therefore, this study looked into GIP as a firm's dynamic capabilities that seek to improve environmental activities and respond to the external natural environment suggested by the NRBV scholars (Hart, 1995; Hart \& Dowell, 2011). From the NRBV, GIP is the process that aims to reduce pollution, controlling and managing ecofriendly products, and then develop a sustainable environment (Hart \& Dowell, 2011; Rehman et al., 2020). Thus, GIP helps GEO to achieve superior environmental performance (Corrocher \& Solito, 2017). In doing so, there is a distinctly practical and theoretical gap that extant literature has overlooked between GEO, GIP, and EP. Therefore, this paper possesses significant implications for academicians, policymakers, and entrepreneurs.

While green innovation reflects firms' capacity to improve eco-friendly products and existing processes, avoid hazardous waste, use eco-raw material, and apply green engineering (Rehman et al., 2020). These results are consequences of green exploitation and exploration capacities. Green absorptive capacity (GAC), therefore, is the capability that allows firms to acquire, assimilate, and deploy new knowledge responding to external threats and aiming at capturing environmental business opportunities (AlbortMorant, Leal-Rodríguez, \& De Marchi, 2018). This insightfulness of knowledge yielded over long years of experiences, which led to GEO activities' support and reconfigured the entire green business structure (Aboelmaged \& Hashem, 2019). Hence, GAC is seen as a dynamic capability that reconfigures the business structure and fosters GEO's learning process to respond to external environmental responsibilities.

Past studies argue that absorptive capacity significantly impacts entrepreneurial orientation and firm performance (Engelen, Kube, Schmidt, \& Flatten, 2014). An empirical study (Sciascia, D'oria, Bruni, \& Larraneta, 2014) found that high absorptive capacity increases entrepreneurs' impact on a firm's performance. Whereas (Hughes, Hodgkinson, Hughes, \& Arshad, 2018) empirically find that GAC strengthens the impact of entrepreneurs on SMEs innovation performance. Besides, it is suggested that AC improves the relationship between green innovation and environmental performance (EP). 
Understanding how GAC coupled with GEO initiatives to foster GIP and EP is essential and theoretically is an outstanding gap. By applying underpinning theory, this research approaches the NRBV lens to extend dynamic capability view (DCV) in explaining how GAC coupled with GEO to improve green innovation and thereby expected to overcome environmental responsibilities.

GAC helps firms create knowledge and skills to support environmental activities by reengineering business processes, deploying new skills and learning, and upgrading training programs to fit environmental standards (Albort-Morant et al., 2018). These environmental concerns usually are the central issue of top management. A study by Tang et al. (2018) indicated that managerial environmental concerns (MEC) increased performance capability when engaging in green innovation processes. In another study, Xue, Boadu, and Xie (2019) suggested that when MEC involved more in eco-innovation activities, environmental performance increased stronger (Saudi, Sinaga, \& Zainudin, 2019). The NRBV advocates that to achieve superior environmental performance, firms must stand on three main criteria: minimizing pollution, approaching eco-friendly products, and enhancing environmentally sustainable development. Thus, these three criteria reflect the firm's environmental concerns responsibility. From the NRBV lens, this study examined MEC as a dynamic capability that fosters environmental activities and responds to the external natural environment. Yet studies delineated the impact of MEC and GEO on GIP to achieve environmental performance.

Moreover, environmental collaboration (EC) significantly impacts green practices (Kong, Feng, \& Ye, 2016) and GEO capabilities to capture eco-friendly opportunities. Besides, networks and inter-organizational relationships would promote sharing common benefits, experiences, and knowledge spillover within and between partners (Weber \& Heidenreich, 2018). This could help entrepreneurs to understand the complicated behaviors of markets, customers, and competitors. And thus, increasing knowledge sources to adopt with all environmental changes. Jack, Moult, Anderson, and Dodd (2010) emphasized the critical impact of an entrepreneur's network on business processes changes over time (Anderson, Dodd, \& Jack, 2012). An empirical study by (Higgins \& Yarahmadi, 2014) found that external collaboration facilitates introducing environmental innovation activities within the production system. Understanding the process of how EC interacted with GEO to convert external environmental activities into green practices is a crucial practical responsibility and, theoretically, is a novel study.

By applying the NRBV and DCV as a supported theory, this study aims to explain the process of how GEO is coupled and improved by GAC, MEC, and EC to capture environmental opportunities through facilitating green environmental activities. Furthermore, our research contributes to entrepreneurship and ecoinnovation literature. Advancing the NRBV lens and overcome the deficiencies observed in DCV, the study seeks to answer the following questions: (1) Does GEO emphasized GIP activities and environmental performance? (2) To what extent does GEO mediate the relationship between green absorptive capacity, environmental cooperation, and MEC on GIP and EP? (3) Does GIP positively impact environmental performance? (4) To what extent MEC will moderate the relationship between GEO and EP? Following the literature review, a description of the methodology applied was presented. Ensuring that a discussion of 
the relevant findings was put forward. Next, the implications of the study from practical and theoretical perspectives were also furnished.

\section{Theoretical background and hypotheses development Green absorptive capacity (GAC) and green entrepreneurship orientation (GEO)}

Environmental entrepreneurship searching for eco-friendly opportunities for reducing pollution and improving sustainable environmental development. GEO is the proactive capability to alter and sense the surrounding restrictions and opportunities determined by time and place (Patel, 2019). Eco-friendly product and process is the key that constitutes GEO (Demirel, Li, Rentocchini, \& Tamvada, 2019). This can be achieved by deploying clean technology and advanced systems that reduce hazardous waste, green training programs, workshops, green empowerment behavior, and green raw materials that these exploitation environmental activities (Rehman et al., 2020) estimated to influence its environmental performance. On the other hand, GAC helps firms spread green knowledge and determine core environmental activities that must be explored and exploited (Aboelmaged \& Hashem, 2019; CepedaCarrion, Martelo-Landroguez, Leal-Rodríguez, \& Leal-Millán, 2017). For example, green exploration refers to those activities that must be applied to new technologies and advanced processes, which in turn led to positively impact firms to generate clean energy and eco-product and hence, enhancing environmental sustainability (Hart \& Dowell, 2011). Zahra, Filatotchev, and Wright (2009) acknowledged AC as one of the main determinants of entrepreneurs' success by enabling firms to build up new skills and business knowledge and reduce cognitive toughness, resulting in exploring and recognizing green opportunities.

Furthermore, $\mathrm{Ng}$ (2007) argues that AC supports entrepreneurs in exploring and mobilizing new resources to exploit eco-friendly opportunities. Besides, Engelen et al. (2014) argued that AC encourages GEO to deal with the uncertain environment by introducing environmental solutions to update green practices and explore opportunities. AC's core role is to create new knowledge (information), which supports entrepreneurs' cognitive skills and proactive behavior to quick environmental scanning and recognition capacity to detect opportunities and understand competitors' reactions (Zhang, Liang, Feng, Yuan, \& Jiang, 2020). With high absorptive capacity, firms can quickly and accurately understand these information resources, combine the acquired information with existing ones effectively, and promote the transformation of new knowledge-the efficiency of transforming this knowledge into products and services increases (Engelen et al., 2014). This strategically led to motivating innovation activities (Sciascia et al., 2014).

Eco-entrepreneurial with sufficient AC is often to explore eco-market opportunities, access to market information, tracking customers' information and preferences (Patel, Kohtamäki, Parida, \& Wincent, 2015); in doing so, they pertinently develop green technologies to improve environmental and organizational performance (Zahra et al., 2009). Overall, AC enables entrepreneurs to promote green technology innovation. Recently, Patel (2019) studied how AC helps entrepreneurs determine and deal 
with opportunities during the development stage and stimulate their cognitive skills and alertness. Sciascia et al. (2014) empirically found that AC strengthens EO activities' impact on firm performance. Another empirical study by Engelen et al. (2014) indicated that AC increasing EO's effect on firm performance when market turbulence is high, suggesting that $A C$ is a parameter that controlling and enabling entrepreneur activities to achieve high environmental performance. An empirical study (Engelen et al., 2014) examined the moderation effect of $A C$ on the relationship between EO, and firm performance were the results indicate that $\mathrm{AC}$ strengthens the EO-firm performance in turbulent market.

In the context of entrepreneurship and innovation, prior studies (Aboelmaged \& Hashem, 2019; Engelen et al., 2014; Patel, 2019; Xue et al., 2019) have used AC as a determinant, moderation, and mediation on the relationship between EO, innovation, and firms' performance. Addressing environmental issues through eco-innovation in the presence of $A C$ is utmost overlooked. Past studies examined the role of $A C$ between EO and innovation outcomes separately, which led to yield inconclusive results and further debates about GAC's potential impact on the relationship between entrepreneurial ecosystem and their consequences on firms, individuals, and eco-system itself. Literature failed to provide any evidence about GAC's effects on GEO, GIP, and EP in a single model, how GAC encourages GEO proactively capabilities to address environmental opportunities still ambiguous and needs further investigations. Therefore, this study aims to fill this crucial gap by linking GAC-GEO to estimate GIP and EP's coupled effects. This study's findings will open new rooms in the research stream and support environmental entrepreneurship and ecoinnovation literature and extend the body of knowledge of dynamic capability theory. In this study, GAC is viewed as a dynamic capability that strategically helps entrepreneurs alter environmental opportunities proactively. Thus, this study hypothesizes that:

\section{H1a: GAC positively influences green entrepreneurship orientation.}

Dynamic capability views green entrepreneurship as a proactive action taken to face unexpected environmental circumstances and ensure businesses' continuity (Jiang et al., 2018). Whereas GAC is the process of an organizational capacity to detect, absorb, and integrate newly acquired knowledge into the existing corporate processes (L. M. Pacheco, Alves, \& Liboni, 2018). This could upgrade new skills and practices, routines, functions, know-how, and reconfiguring production systems (Xue et al., 2019). And thus, driving strategic resource creation affording long-term advantages (Grimpe Kaiser, 2010). Consequently, this study argued that the success of entrepreneur environmental proactive capability is highly associated with GAC. Green innovation is applying new ideas, leveraging environmental practices, green workplaces, green programs, and techniques to foster resource efficiency, pollution reduction, and eco-system (Rehman et al., 2020). AC, therefore, is the primary key source for penetrating green innovation activities (Zhang et al., 2020). Accordingly, GIP and GAC fall within the natural resource-based view's core focus (Hart \& Dowell, 2011). Thus, we believe that this will improve the natural environment (Hart, 1995) and enhance GEO capabilities (Guo et al., 2020; Patel, 2019).

Empirical studies Albort-Morant et al. (2018); Aboelmaged and Hashem (2019); and (L. M. Pacheco et al., 2018) have emphasized the potential role of $A C$ in fostering green innovation activities and its 
consequences on different performance measures. While other studies (Engelen et al., 2014; IbarraCisneros \& Hernandez-Perlines, 2019; Sciascia et al., 2014) have focused on the role of AC in enabling entrepreneurial capabilities to estimate entrepreneurial opportunities. However, predicting environmental opportunities that are the core expertise of this study is of utmost poor in the literature. Understanding the process of how GAC and GEO coupled together to tackle environmental issues and capture ecofriendly opportunities is a new research venture that this study is seeking to practical filled it and theoretically delineated it. By embedding GAC practices within GEO activities, it is surely believed that entrepreneur's alertness to predict eco-business opportunities able to be achieved. To overcome this critical gap in the literature, this study intends to examine the coupled impact of GAC-GEO to improve green practices and environmental performance. Drawing upon the NRBV and DCV lenses, the next hypotheses are proposed:

\section{H1b: GEO mediates the relationship between green absorptive capacity and green innovation} performance.

H1c: GEO mediates the relationship between green absorptive capacity and environmental performance.

\section{Effect of managerial environmental concern (MEC) on GEO}

GEO seeks to capture environmental opportunities and enhance environmental performance.

Entrepreneurs acknowledged that green practices are the primary leading driver of environmental opportunities (Guo et al., 2020). Therefore, managerial environmental concern plays a significant role in addressing these environmental issues to foster GEO capabilities (Ebrahimi \& Mirbargkar, 2017). Top management commitment continuously searches to support and spread green culture across firms' activities (Cao \& Chen, 2019). Top managers should careful and focus on improving those activities that environmentally threaten GEO goals (Jiang et al., 2018). Van Doorn, Heyden, and Volberda (2017) argued that top managers struggle to facilitate GEO due to the fast uncertainty associated with dynamic environments. Hence, this study questions how top-managers able to improve GEO initiatives in a dynamic environment? So far, earlier studies show that firms still vary in their capacity to support GEO to address uncertainty in high dynamic environments (Jiang et al., 2018).

As such, there is a critical gap in our understanding of the role of the top manager's capabilities in fostering or impeding entrepreneurs' environmental opportunities. Top managers had a crucial impact on tracking and interpreting eco-opportunities (Van Doorn, Heyden, Tröster, \& Volberda, 2015) and then adjusting the core focus of entrepreneurial strategies to fit it (Van Doorn, Jansen, Van den Bosch, \& Volberda, 2013). Empirical studies Saudi et al. (2019), and Tang et al. (2018) found that managers' environmental awareness is strongly associated with green practices. In an empirical study, Cao and Chen (2019) stated that top-managers' environmental awareness substantially impacts penetrating internal and external environmental impacts on green innovation practices. This means that the effect of MEC on environmental entrepreneurship exists and how this occurs still ambiguous. Given this critical matter, GEO engagement is more a matter of top-management about environmental concerns and strategic decision-making than a matter of best practices or specified business policy (Xue et al., 2019). From the NRBV lens, we can find evidence about the importance of environmental activities on the 
success of a firm's competitive advantages (Hart \& Dowell, 2011). Thus, the following hypothesis is put forward:

H2a: MEC positively influences green entrepreneurship orientation.

Past empirical studies Tang et al. (2018); Saudi et al. (2019); and Xue et al. (2019) stated that MEC is one of the determinant factors that supporting green innovation practices and environmental performance. MEC emphasized environmental issues by internally solving those activities that contribute to environmental problems to facilitate tracking green opportunities (Xue et al., 2019). This would be resulted in encouraging GEO to explore eco-friendly opportunities (Van Doorn et al., 2017). Dynamic capability theory asserted that top managers are crucial for successful searching and capturing entrepreneurial opportunities (Teece, 2016). While the NRBV advocates that firms should harmonize their relationship with the external natural environment to avoid further eco-system destruction (Hart \& Dowell, 2011). From these both lenses, it can be seen the great responsibility of top-management commitment. The primary task of managers' environmental awareness is to find and solve those environmental activities (Jang, Zheng, \& Bosselman, 2017), thus leading GEO readiness to capture eco-opportunities (Ebrahimi \& Mirbargkar, 2017). It is far away to search for entrepreneurial opportunities if firm GEO cannot solve its environmental impacts. MEC is one of the leading green dynamic capabilities that enable entrepreneurs to capture green opportunities (Nordin \& Hassan, 2019).

Besides, top managers regarded GIP as a severe issue that can foster business growth and protect against environmental degradation [12]. In turn, devote more considerable attention, time, and support to potentially strengthening the impact of green innovation on different environmental aspects (El-Kassar \& Singh, 2019)-hence responding to business environmental changes. In this study, MEC is the cognitive awareness of managers on strengthening GEO activities by applying environmental innovation strategies to yield eco-friendly products that respond to ecological aspects. This study assumed that the more MEC involved in environmental innovation, the greater GEO could capture opportunities and ensure business survival and environmental performance. Prior studies (Saudi et al., 2019; Tang et al., 2018) found that MEC strengthens the relationship between green innovation and organizational and environmental performance. While addressing the direct impact of MEC on GEO is poorly ignored in the literature. Also, handling MEC's interaction impact-GEO on environmental performance and green innovation practicesstill exists. Thus, this study tends to estimate the increased interaction impact of MEC-GEO on enhancing green innovation capabilities and environmental performance from the managerial point of view. Therefore, it is postulated that:

H2b: GEO mediates the relationship between managerial environmental concern and green innovation performance.

H2c: GEO mediates the relationship between managerial environmental concern and environmental performance.

\section{Environmental cooperation (EC) and GEO}


The core focus of green entrepreneurship is fulfilling the environmental requirements of the markets by supplying eco-friendly products and services to improve environmental performance (Guo et al., 2020).To alleviate these environmentally relevant markets, cooperation based environmental innovation (Weber \& Heidenreich, 2018) is a crucial source to do so. In a high uncertainty environment, collaboration and interrelationships with external parties are more valuable and meaningful for acquiring knowledge, practices, skills, and techniques (Hájek \& Stejskal, 2018; Van Beers \& Zand, 2014). An empirical study by Higgins and Yarahmadi (2014) found that collaboration with external partners facilitates environmental innovation within production systems. Cooperation plays a significant role in establishing critical relationships (Wagner \& Llerena, 2011). The core focus of this collaboration (Weber \& Heidenreich, 2018) is developing a corporate green strategy to reconfigure green technologies and then foster green products and processes that would result in exploring and exploiting more opportunities. Hence, collaboration based on environmental innovation strategy supports GEO by developing existing green practices and techniques (Kong et al., 2016). Probably this can lead to the creation of eco-friendly products for those particular environmental markets (Melander, 2017). From the NRBV, addressing environmental activities is the critical success of competitive advantages (Hart \& Dowell, 2011) that managers and entrepreneurs (Rehman et al., 2020). Hence, the next hypothesis is posited:

\section{H3a: Environmental cooperation positively influences green entrepreneurship orientation.}

In a high uncertainty environment, exploring and exploiting entrepreneurial opportunities are quite tricky. Networks and interrelationships with external parties are among the primary sources to overcome these associated issues (Weber \& Heidenreich, 2018). Establishing networks with universities, laboratories, consultants, stakeholders, and government agencies helps firms foster their green innovation capabilities (Higgins \& Yarahmadi, 2014). Such environmental activities are high costs that need green funds, green subsidies, and tax facilities (Van Beers \& Zand, 2014). Therefore, firms must create networks and search for green subsidies to support their green innovation activities (Bai, Song, Jiao, \& Yang, 2019). This can enhance firms' green image, thereby leading to maintaining their competitive advantages (Zameer, Wang, \& Yasmeen, 2020).

Consequently, lead to reduce environmental concerns and improve environmental performance (Kong et al., 2016). Collaboration-based environmental innovation addresses eco-friendly entrepreneurial opportunities, which leads to improved GEO proactively capabilities. A recent empirical study by Kong et al. (2016) in advanced manufacturing technologies found that green innovation (products and processes) is significantly influenced by internal environmental cooperation. Whereas Albort-Morant et al. (2018) assumed that strong interrelationships with external partners could strengthen GIP through assimilation and transfer of new knowledge into the production and managerial system. Since environmental cooperation emphasizes on developing and updating existing green dynamic capabilities to foster GIP to respond and address environmental opportunities (Weber \& Heidenreich, 2018), entrepreneurs' decisions are highly associated with collaboration and meaningful because it pointed out eco-system sustainability. 
An empirical study by Younis, Sundarakani, and Vel (2016) examined the effect of environmental cooperation on Korean electronics firms' financial and non-financial performance. In another study Perotti, Zorzini, Cagno, and Micheli (2012) addressed the impact of environmental collaboration and green supply chain initiatives on adopting green supply chain practices to improve firm performance. While Diabat, Khodaverdi, and Olfat (2013) investigated the effect of cooperation with suppliers, collaboration with customers, and green supply chain practice on different firm performance measures. However, entrepreneurship literature struggles to provide any evidence about EC's direct impact on GEO and EC-GEO's coupled impact on green innovation practices and environmental performance.

Understanding how mechanism cooperation based on environmental concern between partners will foster GEO readiness is of utmost importance (Kobarg et al., 2020). To do so, this study fills an essential theoretical gap that emerged in the entrepreneurship literature. To what extent these networks and collaboration can alert entrepreneurial opportunities is still a new research endeavor. Lack of studies and inadequate understanding of the collaboration process support GEO lead to the debates about the GEO capacities in amelioration environmental markets. This study, therefore, tests the proposed hypotheses as outlined below:

H3b: GEO mediates the relationship between environmental cooperation and green innovation performance.

H3c: GEO mediates the relationship between environmental cooperation and environmental performance.

\section{GEO and green innovation performance}

Environmental degradation is becoming a global concern for all stakeholders, policymakers, and peoples (Kasayanond, Umam, \& Jermsittiparsert, 2019). Environmental entrepreneurship is the key driver in enhancing ecological sustainability by enabling green innovation practices to reduce environmental degradation (Song, Fisher, \& Kwoh, 2019). GEO refers to a proactive strategic orientation that explores and tracks green business opportunities considering a holistic understanding of risks and benefits (Jiang et al., 2018). GEO aims to respond to environmental degradation by producing and supplying eco-friendly products to enhance environmental performance (Nordin \& Hassan, 2019). Responding to these concerns, GEO seeks to achieve the following (1) providing eco-friendly products, (2) reducing waste hazardous and $\mathrm{CO} 2$ emissions, (3) improving green workplace environment, (4) improving job satisfaction and green image. These can be achieved through facilitating and leveraging green practices (Guo et al., 2020; Nasrollahi, Fathi, \& Hassani, 2020). GEO reflects an entrepreneur's penetration behavior and lead markets (Arnold \& Hockerts, 2011). Dynamically mobilizing green innovation of a firm (Guo et al., 2020).

In addition, GEO helps firms proactively and intentionally move toward green practices. Despite that, few studies $[5,33]$ use GEO as an antecedent to study its association impacts on the GIP. To recoup for this imperfection, this study will attempt to address GEO's impact on GIP to improve environmental performance. Pursuing green business growth is becoming the primary goal of entrepreneurs to deal with 
eco-system requirements $(\mathrm{Li}, 2014)$. In this sense, developing green innovation has become an unavoidable choice for entrepreneurs to reduce carbon emissions (H. Sun, Edziah, Sun, \& Kporsu, 2019), advance economic transformation mode, and enhance environmental performance (L.-y. Sun, Miao, \& Yang, 2017). Supporting green innovation capabilities might impede the negative impacts of business activities on the environment (Borghesi, Cainelli, \& Mazzanti, 2015). Recent manufacturers gave more attention to green innovation as a strategic solution to maintain the eco-system and increase organizational performance (L. M. Pacheco et al., 2018). It is critical, therefore, to determine the driving forces for firms to adopt green practices. Gast, Gundolf, and Cesinger (2017) argued that to yield green value-added, fostering GIP utmost the key strategic solution for the entrepreneurial ecosystem (Xue et al., 2019). To what extent GEO will promote GIP to achieve superior environmental performance and ensure business growth is crucial. Thus, the present study hypothesizes that:

\section{H4: GEO has a positive effect on green innovation performance. \\ GEO and environmental performance (EP)}

The increased customer needs and global market demands have led to the fast degradation of natural resources (Yunus \& Michalisin, 2016), which yielded unexpected ecological and socioeconomic concerns (Shun-Pin Chuang \& Huang, 2018). GEO may contribute to superior environmental performance by several mechanisms. First, supplying eco-friendly products and services (Chen \& Chang, 2013). Second, GEO aims to reduce hazardous emissions (Jiang et al., 2018). Third, commitment to consumer safety and health (Shan-Ping Chuang \& Yang, 2014).

Similarly, in addition to the eco-system benefits that drove by GEO, economic benefits might be yielded by three channels, namely, (1) reducing resources cost and saving energy (Xue et al., 2019); (2) being an active entrepreneur in pursuing green eco-friendly opportunities might achieve a first-mover advantage (D. F. Pacheco, Dean, \& Payne, 2010); (3) a willingness to challenge by investing in high uncertainty environment (Woldesenbet, Ram, \& Jones, 2012) -taken together, GEO able to enhance both economic and environmental performance. Thus, GEO develops a corporation's capabilities to facilitate environmental market failure by investing more in environmental activities.

Recent research (Guo et al., 2020; Pratono, Darmasetiawan, Yudiarso, \& Jeong, 2019; Schaefer, Corner, \& Kearins, 2015) suggested that GEO plays a crucial role in achieving better financial performance and minimizing environmental impacts (Ullah \& Qaiser Danish, 2020). GEO is a predisposition to pursue potential opportunities that produce economic and ecological benefits by introducing eco-friendly products and services (Jiang et al., 2018). Although the core motivation and benefits for green entrepreneurship (e.g., economic, environmental, and social value) have been addressed in previous research (Gast et al., 2017; Kirkwood \& Walton, 2014), how GEO influences environmental performance remains unclear. An understanding of the conditions under which GEO influences EP is far from comprehensive. Teece (2014) argues that dynamic capabilities emphasize building and restructuring internal and external resources. This inclination facilitates tracking eco-friendly opportunities to yield green value-added. According to Teece, GEO is a new endeavor to promise new product processes 
(Woldesenbet et al., 2012). Notably, having entrepreneurs with a sufficient green mindset, priorities would be given to reduce pollution production systems (Kong et al., 2016).

Consequently, toxic emissions and hazardous would be impeded, along with decreasing the use of water, electricity, and oil consumption by applying clean technologies (Triguero, Moreno-Mondéjar, \& Davia, 2013). This emphasizes that GEO not only responding to environmental regulations but also fulfilling societal, environmental concerns. In case the utilization of solar energy will mitigate environmental risk and human safety (Dangelico \& Pujari, 2010). It is crucial to comprehensively uncover this topic, which helps firms determine green capabilities that must be applied within core activities to avoid environmental issues and ultimately support clean production systems and improve environmental performance. Based on these contentions, the next hypothesis is put forward:

\section{H5: GEO has a positive impact on environmental performance.}

\section{GIP and environmental performance}

The NRBV lens suggested that firms should determine and emphasize those core activities that generate environmental issues (Hart \& Dowell, 2011). This can be happening when firms focused on three distinct criteria, they are (1) reducing environmental pollution; (2) product stewardship; (3) environmentally sustainable development (Rehman et al., 2020). Standing on this lens to explain the study's core issue, GIP is the crucial strategic solution to achieve the three criteria above. GIP is the practice of rationalizing natural resources and maintaining ecosystems (Rehman et al., 2020) through increasing resource efficiencies (Shun-Pin Chuang \& Huang, 2018). And then enabling entrepreneurs to exploit high market opportunities and ensuring their business advancement (Jiang et al., 2018). Green chemistry and green engineering are core green practices that intend to reduce chemical waste, hazardous, paraxylene, and toxicological associated with these activities and improve a green workplace environment (Matus, Xiao, \& Zimmerman, 2012).

Recently, fast industrial advancement has extensively contributed to ecological problems and global warming (Jiang et al., 2018). As a result, businesses and governments are dealing with critical concerns to ensure future socioeconomic and ecologic (Tang et al., 2018). Therefore, GIP's strategic importance is directed to transform business processes into green business methods (Albino, Balice, \& Dangelico, 2009). The following reasons stimulate the inspiration of entrepreneurs in acquiring a green label. First, it is based on the entrepreneur's personal preferences to apply eco-friendly practices responding to environmental concerns (Dangelico, 2015). Second, fulfilling and responding to the increased customer environmental awareness toward the notion of customer-driven business ideology (Chang \& Fong, 2010). Third, proactive behavior corresponds to markets and government regulations to address business sustainability based on eco-system concerns (Wang, Liu, Hansson, Zhang, \& Wang, 2011).

GIP involves firms' ability to combine green products and processes to create eco-friendly products with less energy use and a clean workplace environment (Chen, Lai, \& Wen, 2006). Also, the green strategy is the practice that leads to improving the existing procedures that emphasize ecological concerns to deliver 
green value-added to the customers without any negative impact on eco-systems (Chen, 2008). Thus, green innovation support efficiency and responsiveness capabilities, adaptability capacity to customer preferences, societal and governmental legislation, which might result in a greater emphasis on environmental concerns (Xue et al., 2019). According to Chen et al. (2006), green innovations reflect the integration of clean technologies with green practices to ensure pollution prevention through reducing energy use and waste hazardous and their consequences on environmental performance. The extent to which green innovation beneficial for an organization is interpreted into the performance that can be achieved in several aspects. Accordingly, it is postulated that:

H6: GIP has a positive effect on environmental performance.

\section{The moderating role of managerial environmental concerns (MEC)}

Managers and executives are playing a significant role in the corporate business strategy (Jang et al., 2017). Business managers and GEO's connectedness helps firms exploit dynamic capabilities and predict future business opportunities (Van Doorn et al., 2017). Managers' environmental awareness is expected to play a significant role in facilitating and deploying green practices. This can enrich the green organizational culture and yield green products and process outcomes (Van Doorn et al., 2017). Therefore, entrepreneurs should plant a green seed to foster managerial environmental awareness. As a result, GEO facilitated their proactive strategies in addressing environmental concerns. Thus, it will be able to solve and enhance environmental performance (Gibbs \& O'Neill, 2014). Several studies (Kirkwood \& Walton, 2014), (Saudi et al., 2019), and (Xue et al., 2019) found that environmental concerns highly influence EO. These concerns usually determined the success of entrepreneurial opportunities (Saunila, Ukko, \& Rantala, 2018).

Past studies Saudi et al. (2019); Tang et al. (2018), and Saudi et al. (2019) have addressed and examined the moderation effect of MEC between green innovation, firm performance, and environmental performance. These studies' results were inconclusive and found that MEC positively moderates the relationship between a green process innovation and firm performance. In contrast, it does not moderate the relationship between green product innovation and firm performance (Tang et al., 2018). These studies have focused on the impact of MEC on fostering green innovation concerning different performance measures. Simultaneously, understanding the process or the nature of MEC and GEO's relationship in addressing green practices and environmental performance has not been examined yet. To what extent that MEC able to alert GEO to absorb entrepreneurial opportunities is still ambiguous. Therefore, this study theoretically extends the body of knowledge of dynamic capability theory by emphasizing the development of dynamic capabilities in addressing environmental activities. By addressing these environmental issues, this study extends the body of the NRBV and provide further support about the importance of caring natural environment to achieve superior environmental performance (Hart \& Dowell, 2011). 
On the other hand, MEC help GEO to explore green opportunities and developing existing ones to suit environmental challenges by (1) addressing opportunities in those market failure, (2) collaboration based environmental innovation, (3) tracking and understanding customer environmental awareness, (4) restructuring business production systems, (5) reducing waste hazardous to provide green workplace environment. These tasks are the key expertise of managers to encourage GEO initiatives. Thus, this study assumes that the more MEC influences GEO, the greater GEO can capture entrepreneurial opportunities. Accordingly, the subsequent hypotheses are posited:

H7a: MEC has a positive influence on environmental performance.

H7b: MEC moderates the relationship between green entrepreneurship orientation and environmental performance.

Based on the discussion, grounding on the natural resource-based view and dynamic capability theory, Fig. 1 illustrates the proposed theoretical framework that explains the core issue of environmental entrepreneurship, eco-innovation, and environmental performance.

\section{Methodology}

\section{Sampling, respondents, and data collection}

This study concerns GEO, GIP, and EP among petroleum and petrochemical firms in China. Appropriate respondents are more important (managers of the production unit, managers of $R \& D$, and managers of environmental protection, marketing managers, and CEO) to provide accurate data to fulfill the study's objectives and then clear demonstrating different relationships between factors of this research. Based on the list of 11140 petrochemical firms registered in the State Administration for Industry and Commerce of the People's Republic of China, this study applies a random sampling technique. Following Krejcie and Morgan (1970) formula, the sample size of this study was 370. As suggested by (Israel, 2003), actions were made to avoid any missing survey along with the low-response rate. Five-hundred eighteen respondents derived from a different department, which consists of middle- to upper-managerial executives in the petrochemical firms across China, were approached to complete the questionnaire.

A dual-language (English and Chinese version) of the questionnaire was sent, followed up by calls and emails, and a cover letter explaining the importance of this study's participation with the utmost confidentiality. Starting from March to July 2019, this study successfully collected 234 questionnaires while excluding eight responses due to incomplete answers representing a response rate of $43.6 \%$. Table 1 details the background of respondents and firms. Respondents were mainly well-educated and had a long working experience, and attended several training programs to improve managerial and interpersonal skills provided by petrochemical firms. This descriptive result infers most firms with a long business operation in the petrochemical industry, acknowledged as China's primary strategic sources. 
Table 1

Background of respondents and firms.

\begin{tabular}{|c|c|c|}
\hline Respondents profile & Frequency & Percentage (\%) \\
\hline \multicolumn{3}{|l|}{ Education } \\
\hline Degree & 95 & $18.3 \%$ \\
\hline Master & 81 & $15.6 \%$ \\
\hline PhD & 23 & $4.4 \%$ \\
\hline Others & 27 & $5.2 \%$ \\
\hline \multicolumn{3}{|l|}{ Years of experience } \\
\hline 1 to 5 years & 31 & $5.9 \%$ \\
\hline 5 to 10 years & 122 & $23.5 \%$ \\
\hline More than 10 years & 73 & $14.1 \%$ \\
\hline \multicolumn{3}{|l|}{ Firms age } \\
\hline $1-5$ years & 19 & $3.7 \%$ \\
\hline 6-10years & 54 & $10.4 \%$ \\
\hline More than 10 years & 153 & $29.5 \%$ \\
\hline \multicolumn{3}{|l|}{ Ownership structure } \\
\hline Private firms & 132 & $25.4 \%$ \\
\hline Collective and state-owned firms & 67 & $12.9 \%$ \\
\hline Foreign firms & 27 & $5.2 \%$ \\
\hline \multicolumn{3}{|l|}{ Position } \\
\hline Production manager & 32 & $6.2 \%$ \\
\hline Engineers & 26 & $5 \%$ \\
\hline Executive director & 41 & $7.9 \%$ \\
\hline Director of the environment & 34 & $6.56 \%$ \\
\hline Managers of Sales \& Marketing & 21 & $4 \%$ \\
\hline Director of R\&D & 18 & $3.8 \%$ \\
\hline CEO & 43 & $8.3 \%$ \\
\hline Others & 11 & $2.1 \%$ \\
\hline Number of employees & & \\
\hline
\end{tabular}




\begin{tabular}{|llll|}
\hline Respondents profile & Frequency & Percentage (\%) \\
\hline Less than 100 & 55 & $10.6 \%$ \\
\hline 100 to 250 & 64 & $12.3 \%$ \\
\hline 251 to 500 & 76 & $14.7 \%$ \\
\hline More than 500 & 31 & $5.9 \%$ \\
\hline
\end{tabular}

\section{Measurement of variables}

Ensuring the adequacy, clarity, smoothness of items understanding and distinguishing every group of items reflects only one particular variable among other research variables. In-depth content validity was conducted by inviting two experts to enrich the measurement items' content, followed by an interview with four professional experts in petrochemical firms in Guangdong provinces, China. Then, the output from academics and professional experts was carefully incorporated into the survey's final draft. To this end, 16 companies are randomly selected and personally contacted managers to participate in a pilot study. The results showed that all variables' internal consistency and composite reliability ranged from 0.823 to 0.915 , indicating a high-reliability coefficient. After that, the survey items are adjusted accordingly and then establishing a final version, which translated into the Chinese language.

The measurement used to estimate this study's variables were adapted from past studies and adopted to the Chinese petrochemical industry context to fit the study's objective. To measure green absorptive capacity, this study adopts items from L. M. Pacheco et al. (2018). Managerial environmental concern items were adopted from Xue et al. (2019), and Saudi et al. (2019). Moreover, environmental cooperation items were adopted from the works of Younis et al. (2016), and Vachon and Klassen (2006). The items were adopted from Chen, Lai [75], and Pacheco, Alves [31] for measuring green innovation performance. Green entrepreneurship orientation was adopted from Jiang et al. (2018). Next, items measuring environmental performance were adopted from El-Kassar and Singh (2019) and Jiang et al. (2018). The data were collected through a 7-point Likert scale ranging from $1=$ (strongly disagree) to $7=$ (strongly agree).

In this study, firm size (number of employees) and firm age (years of operation) were introduced as control variables. Firm size was operationalized based on the number of employees (Berrone, Fosfuri, Gelabert, \& Gomez-Mejia, 2013; Tang et al., 2018), encompassing four categories. Firm age was operationalized based on years of operation (Tang et al., 2018; Westman \& Thorgren, 2016), emphasized into three categories. The basis for introducing these control variables because firms might not have the power and experiences of the same resource, which impacts environmental innovation development from the company to other ones.

\section{Data analysis}

The Partial Least Square Structural Equation Modeling (PLS-SEM) was performed via SMART PLS 3.0 software for better predicting and assessing measurement model (convergent and discriminant validity) 
and structural model (Henseler, Ringle, \& Sarstedt, 2015). The rationale for the selection is that: (1) PLSSEM allow the researcher to maximize the predictive precision of endogenous factors while maintaining more items for each factor, (2) the sample data of this study was not normal distribution (Chin, 1998), (3) sample size of this research is adequate to be analyzed by PLS-SEM, (4) the model of this study is complicated (mediation and moderation path). Thus PLS-SEM is suitable for predictive purposes (AlbortMorant, Leal-Millán, \& Cepeda-Carrión, 2016). This study assessed the validity and reliability of the measurement items. It then examined the structural model by determining the path coefficient's significance, the effect size of endogenous factors on exogenous ones, and determining value $\left(R^{2}\right)$. Lastly, by applying the blindfolding procedure, the research model's relevance $\left(Q^{2}\right)$ was tested as recommended by (Joe F Hair Jr, Sarstedt, Hopkins, \& Kuppelwieser, 2014).

An independent samples t-test was checked to assess whether any possibility of non-response bias (the differences between early and late respondents that might share the same characteristics). The study found that Levene's test for equality of variance was higher than the 0.05 of all constructs, fulfilling the significance level requirement based on (Pallant, 2011). Hence, suggesting that this study is free of nonresponse bias. Besides, to ensure and safe the validity of the overall relationships in the model, detecting any measurement errors is essential by checking whether it is free of common method variance (CMV) by applying a full collinearity test. The estimated observed values of variance inflation factors (VIFs) generated for all factors must be below 3.3 (Kock, 2015); the results indicated that the model was free of CMV.

\section{Validity and reliability of the measurement model}

Measurement model assessment consists of convergent validity and discriminant validity. The indicator's outer loading, factor loading, composite reliability, and average variance extracted (AVE) were evaluated for measuring convergent validity. As shown in Table 2, all item loadings were higher than 0.70 (Joe $F$ Hair Jr et al., 2014). Likewise, all constructs' composite reliability was larger than 0.70 (Chin, 1998), while AVE values were bigger than 0.50, as suggested by (Joseph F Hair Jr, Sarstedt, Ringle, \& Gudergan, 2017). 
Table 2

Measurement model results.

\begin{tabular}{|c|c|c|c|c|c|}
\hline Construct & Item & Loading & CA & $\mathrm{CR}$ & AVE \\
\hline \multirow[t]{8}{*}{ Environmental Cooperation } & EC1 & 0.879 & \multirow[t]{8}{*}{0.931} & \multirow[t]{8}{*}{0.948} & \multirow[t]{8}{*}{0.785} \\
\hline & EC 2 & 0.847 & & & \\
\hline & EC 3 & 0.928 & & & \\
\hline & EC 4 & 0.908 & & & \\
\hline & EC 5 & 0.896 & & & \\
\hline & EC 6 & - & & & \\
\hline & EC 7 & - & & & \\
\hline & EC 8 & - & & & \\
\hline \multirow[t]{10}{*}{ Green Absorptive Capacity } & GAC1 & 0.702 & \multirow[t]{10}{*}{0.933} & \multirow[t]{10}{*}{0.944} & \multirow[t]{10}{*}{0.653} \\
\hline & GAC 2 & 0.754 & & & \\
\hline & GAC 3 & 0.793 & & & \\
\hline & GAC 4 & 0.887 & & & \\
\hline & GAC 5 & 0.775 & & & \\
\hline & GAC 6 & 0.872 & & & \\
\hline & GAC 7 & 0.836 & & & \\
\hline & GAC 8 & 0.822 & & & \\
\hline & GAC 9 & 0.813 & & & \\
\hline & GAC 10 & - & & & \\
\hline \multirow{4}{*}{$\begin{array}{l}\text { Managerial Environment } \\
\text { Concern }\end{array}$} & MEC 1 & 0.863 & \multirow[t]{4}{*}{0.939} & \multirow[t]{4}{*}{0.955} & \multirow[t]{4}{*}{0.841} \\
\hline & MEC 2 & 0.931 & & & \\
\hline & MEC 3 & 0.939 & & & \\
\hline & MEC 4 & 0.934 & & & \\
\hline \multirow{4}{*}{$\begin{array}{l}\text { Green Innovation } \\
\text { Performance }\end{array}$} & GIP 1 & 0.838 & \multirow[t]{4}{*}{0.890} & \multirow[t]{4}{*}{0.914} & \multirow[t]{4}{*}{0.602} \\
\hline & GIP 2 & 0.729 & & & \\
\hline & GIP 3 & 0.805 & & & \\
\hline & GIP 4 & 0.789 & & & \\
\hline
\end{tabular}




\begin{tabular}{|c|c|c|c|c|c|}
\hline Construct & Item & Loading & CA & CR & AVE \\
\hline & GIP 5 & - & & & \\
\hline & GIP 6 & - & & & \\
\hline & GIP 7 & - & & & \\
\hline & GIP 8 & 0.766 & & & \\
\hline & GIP 9 & 0.740 & & & \\
\hline & GIP 10 & 0.761 & & & \\
\hline \multirow{5}{*}{$\begin{array}{l}\text { Green Entrepreneurial } \\
\text { Orientation }\end{array}$} & GEO 1 & - & 0.843 & 0.894 & 0.679 \\
\hline & GEO 2 & 0.832 & & & \\
\hline & GEO 3 & 0.808 & & & \\
\hline & GEO 4 & 0.833 & & & \\
\hline & GEO 5 & 0.822 & & & \\
\hline \multirow[t]{6}{*}{ Environmental Performance } & EP 1 & 0.924 & 0.954 & 0.963 & 0.812 \\
\hline & EP 2 & 0.913 & & & \\
\hline & EP 3 & 0.897 & & & \\
\hline & EP 4 & 0.887 & & & \\
\hline & EP 5 & 0.879 & & & \\
\hline & EP 6 & 0.907 & & & \\
\hline
\end{tabular}

The discriminant validity was evaluated via the Fornell and Larcker criterion to assess the comparison of correlation between constructs with the square root of the AVE of the constructs. As shown in Table 3, the diagonals' bolded values were higher than the values in their respective row and column, thus indicating that the measures used in this study were discriminant. The cross-loading criterion was also assessed, and results showed that outer loading exceeded cross-loading for all constructs, and then results remained valid. Additionally, Heterotrait-Monotrait (HTMT) ratio developed by (Henseler et al., 2015) was also evaluated to check further that the model is well-examined. The values presented in parentheses in Table 3 is less than 0.85 and met the criterion of HTMT .85 (Kline et al., 2012), indicating that discriminant validity was achieved and the confidence interval does not show a value of 1 on any of the variables (Henseler et al., 2015), which means discriminant validity was confirmed. 
Table 3

Fornell-Larcker Criterion and Heterotrait-Monotrait Ratio (HTMT).

\begin{tabular}{|llllllll|}
\hline Variable & EC & EP & GAC & GEO & GIP & MEC \\
\hline EC & .792 & & & & & \\
EP & .712 & .803 & & & & \\
& $(.69)$ & & & & & \\
GAC & .732 & .704 & .781 & & & \\
& $(.67)$ & $(.80)$ & & & & \\
GEO & .743 & .675 & .678 & .792 & & \\
& $(.77)$ & $(.69)$ & $(.78)$ & & & \\
GIP & .675 & .643 & .649 & .632 & .813 & \\
& $(.71)$ & $(.58)$ & $(.65)$ & $(.67)$ & & \\
MEC & .532 & .382 & .452 & .472 & .542 & .774 \\
& $(.47)$ & $(.52)$ & $(.42)$ & $(.56)$ & $(.36)$ & \\
\hline
\end{tabular}

\section{Structural model}

The structural path in Fig. 2 and Table 4 showed a positive and significant relationship between GAC and GEO $(\beta 1 \mathrm{a}=0.438, \mathrm{t}=8.95, \mathrm{p}<0.000)$, indicating that $\mathrm{H} 1 \mathrm{a}$ is supported. Next, the managerial environmental concern path was positive and statistically significant on GEO $(\beta 2 a=0.076, t=1.79, p<$ 0.003), inferring that the hypothesis $\mathrm{H} 2 \mathrm{a}$ is retained. Moreover, environmental cooperation has a positive and significant effect on GEO ( $\beta 3 a=0.109, t=2.31, p<0.001)$, denoting that $\mathrm{H} 3 \mathrm{a}$ is maintained. Furthermore, the results showed that GEO was positively and significantly influence GIP $(\beta 4=0.288, t=$ $5.89, p<0.000)$ and $\operatorname{EP}(\beta 5=0.343, t=7.24, p<0.000)$, respectively, signifying that $\mathrm{H} 4$ and $\mathrm{H} 5$ was supported. In addition, GIP has a significant and positive effect on $\operatorname{EP}(\beta 6=0.234, t=5.04, p<0.001)$, which means $\mathrm{H} 6$ is supported. Additionally, the effect of managerial environmental concerns on EP ( $\beta 7 a$ $=0.337, t=5.30, p<0.000$ ) was positive and significant. Hence, supporting $7 a$ is upheld. 
Table 4

Results of structural model analysis.

\begin{tabular}{|c|c|c|c|c|c|c|c|}
\hline Hypotheses & Relationships & Beta & $t$-value & $p$-value & $R^{2}$ & $f^{2}$ & Decision \\
\hline $\mathrm{H} 1 \mathrm{a}$ & GAC $\rightarrow$ GEO & 0.438 & 8.953 & 0.000 & \multirow[t]{3}{*}{$26.4 \%$} & 0.212 & Supported \\
\hline $\mathrm{H} 2 \mathrm{a}$ & MEC $\rightarrow$ GEO & 0.076 & 1.797 & 0.003 & & 0.145 & Supported \\
\hline $\mathrm{H} 3 \mathrm{a}$ & EC $\rightarrow$ GEO & 0.109 & 2.313 & 0.001 & & 0.097 & Supported \\
\hline $\mathrm{H} 4$ & GEO $\rightarrow$ GIP & 0.288 & 5.894 & 0.000 & $14.6 \%$ & 0.093 & Supported \\
\hline H5 & GEO $\rightarrow$ EP & 0.343 & 7.248 & 0.000 & \multirow[t]{3}{*}{$47.8 \%$} & 0.164 & Supported \\
\hline H6 & GIP $\rightarrow$ EP & 0.234 & 5.049 & 0.000 & & 0.087 & Supported \\
\hline $\mathrm{H} 7 \mathrm{a}$ & MEC -> EP & 0.337 & 5.306 & 0.000 & & 0.103 & Supported \\
\hline
\end{tabular}

\section{The effect size of the model}

The effect size $\left(f^{2}\right)$ of constructs on a particular dependent variable explains how these factors are connected and affect GEO simultaneously shows the model's strength (Joe F Hair Jr et al., 2014). $f^{2}$ values of $0.02,0.15$, and 0.35 are considered small, medium, and large effect sizes, respectively (Cohen, 1988). As tabulated in Table 4, GAC's effect size on GEO and GEO on EP was medium, whereas all other constructs show a small effect size. Moreover, all these constructs are contributing and explaining the high-value variance of $R^{2}$ of $26.4 \%$ on green entrepreneurship orientation, GIP $\left(R^{2}=14.6 \%\right)$, and EP $\left(R^{2}=\right.$ $47.8 \%$ ), suggesting that the most reliable relationship with all dependent variables (see Table 8 ). The study also examined the effect of a firm's age (years of operation) and their size (number of employees) as control variables. Results shows firm size $(\beta=-0.147, t=3.04, p>0.05)$, and firm's age $(\beta=-0.117, t=$ $1.69, p<0.10)$ were statistically significant on environmental performance. Both control variables significantly impact EP, indicating that these firms acquire enough experiences and resources to support environmental innovation initiatives.

\section{Testing mediation effect}

GEO's mediation effect between GAC, EC, and MEC on GIP and EP was assessed by using (Preacher \& Hayes, 2004, 2008)'s approach and using the bootstrapping procedure to test the indirect effect as suggested in the literature. The result presented in Table 5 shows that GAC's indirect effect on GIP has a beta value of 0.126 and t-value of 4.29, respectively. As recommended by (Hair, Ringle, \& Sarstedt, 2013), the variance accounted for (VAF) that determines the indirect effect size in relation to the total effect was calculated. In this study, the VAF = direct effect/total effect has a value of $0.126 / 0.438=0.287$, indicating that $28.7 \%$ of GAC effect on GIP is explained via the existence of the mediation effect of GEO. Since the VAF is greater than $20 \%$ but less than $80 \%$, inferring that GEO partially mediates this relationship, hence $\mathrm{H} 1 \mathrm{~b}$ is supported. Moreover, the indirect effect of GAC on EP has $B=0.15, \mathrm{t}=4.81$, respectively. Hence, the 
$\mathrm{VAF}=0.15 / 0.438=0.342$, deducing that GEO's mediation effect explains $34.2 \%$ of the GAC effect on EP. Thus, this relationship is partially mediated, hence retaining $\mathrm{H} 1 \mathrm{c}$.

Table 5

Indirect effects in the mediation model.

\begin{tabular}{|c|c|c|c|c|c|c|c|}
\hline \multicolumn{2}{|c|}{ Relationship } & \multirow[t]{2}{*}{ Beta } & \multirow[t]{2}{*}{$t$-value } & \multirow[t]{2}{*}{$p$-Value } & \multicolumn{2}{|c|}{ Confidence Interval } & \multirow[t]{2}{*}{ Decision } \\
\hline & & & & & $5 \%$ & $95 \%$ & \\
\hline $\mathrm{H} 1 \mathrm{~b}$ & GAC $\rightarrow$ GEO $\rightarrow$ GIP & 0.126 & 4.297 & $0.00 \star \star \star$ & 0.08 & 0.177 & Supported \\
\hline $\mathrm{H} 1 \mathrm{c}$ & GAC $\rightarrow$ GEO $\rightarrow$ EP & 0.150 & 4.817 & 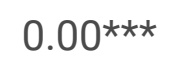 & 0.10 & 0.201 & Supported \\
\hline $\mathrm{H} 2 \mathrm{~b}$ & MEC $\rightarrow$ GEO $\rightarrow$ GIP & 0.022 & 1.728 & 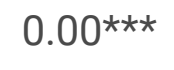 & 0.002 & 0.043 & Supported \\
\hline $\mathrm{H} 2 \mathrm{C}$ & $\mathrm{MEC} \rightarrow \mathrm{GEO} \rightarrow \mathrm{EP}$ & 0.026 & 1.845 & 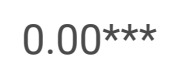 & 0.002 & 0.049 & Supported \\
\hline $\mathrm{H} 3 \mathrm{~b}$ & $\mathrm{EC} \rightarrow \mathrm{GEO} \rightarrow \mathrm{GIP}$ & 0.031 & 1.739 & 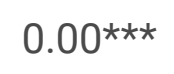 & 0.008 & 0.06 & Supported \\
\hline $\mathrm{H} 3 \mathrm{c}$ & $\mathrm{EC} \rightarrow \mathrm{GEO} \rightarrow \mathrm{EP}$ & 0.037 & 2.255 & $0.00 * \star \star$ & 0.011 & 0.065 & Supported \\
\hline
\end{tabular}

Moreover, the VAF for $\mathrm{H} 2 \mathrm{~b}$ and $\mathrm{H} 2 \mathrm{c}$ was $28.9 \%$ and \%34.2, respectively, indicating that GEO partially mediated the relationship between MEC, GIP, and EP. Thus, $\mathrm{H} 2 \mathrm{~b}$ and $\mathrm{H} 2 \mathrm{c}$ are supported. Further, GEO's mediation effect between environmental cooperation and GIP were $\beta=0.031, t=1.73, p<0.001$. The VAF value of $0.031 / 0.109=0.284$, implying that GEO's mediation effect explained $28.4 \%$ of the EC effect on GIP. Thus, the relationship partially mediated. Henceforth, H3b is supported. GEO's mediation effect on the relationship between EC and EP was significant, indicating a mediation effect $(\beta=0.037, t=2.25, p<$ 0.001 ). The VAF has a value of $0.037 / 0.109=0.339$, showing that $33.9 \%$ of EC effect on environmental performance has occurred in the existence of the mediation effect of GEO. Thereby H3c is maintained (see Table 5 and Table 6). 
Table 6

Variance Accounted for (VAF) of the Mediator Variable for GEO and SEP.

\begin{tabular}{|lllllc|}
\hline $\begin{array}{l}\text { Independent } \\
\text { variable }\end{array}$ & $\begin{array}{l}\text { Mediator } \\
\text { variable }\end{array}$ & $\begin{array}{l}\text { Dependent } \\
\text { variable }\end{array}$ & $\begin{array}{l}\text { Indirect } \\
\text { effect }\end{array}$ & $\begin{array}{l}\text { Total } \\
\text { effect }\end{array}$ & VAF (\%) \\
\hline GAC & GEO & GIP & 0.126 & 0.438 & 28.7 \\
\hline GAC & GEO & EP & 0.150 & 0.438 & 34.2 \\
\hline MEC & GEO & GIP & 0.022 & 0.076 & 28.9 \\
\hline MEC & GEO & EP & 0.026 & 0.076 & 34.2 \\
\hline EC & GEO & GIP & 0.031 & 0.109 & 28.4 \\
\hline EC & GEO & EP & 0.037 & 0.109 & 33.9 \\
\hline $\begin{array}{l}\text { Note: GAC, green absorptive capacity; MEC, managerial environmental concern; EC, environmental } \\
\text { cooperation; GIP, green innovation performance; GEO, green entrepreneurship orientation; EP, } \\
\text { environmental performance. }\end{array}$ & \multicolumn{4}{|l}{} \\
\hline
\end{tabular}

\section{Testing the moderation effect}

To test MEC's moderation effect on the relationship between GEO and EP, the study applied a product indicator approach by (Henseler \& Fassott, 2010) to assess the strength of the moderation effect of MEC. Table 7 details that the positive interaction between MEC and GEO $(\beta=0.095, t=2.08, p<0.001)$; was statistically significant, conjecturing that MEC strengthens the relationship between GEO and EP. Hence $\mathrm{H} 7 \mathrm{C}$ is supported.

Table 7

Results of moderation effect of environmental regulation.

\begin{tabular}{|lllllll|}
\hline & Relationship & Beta & $\begin{array}{l}\text { t-value } \\
\text { 2 tailed }\end{array}$ & p-value & $f^{2}$ & Decision \\
\hline H7b $\quad$ MEC * GEO $\rightarrow$ EP & 0.095 & 2.082 & 0.001 & 0.11 & Supported \\
\hline Note: $t$-value $>1.96$. & & & & & \\
\hline
\end{tabular}

Figure 3 illustrates that the moderator variable MEC's presence affects the intensity of the positive relationship between GEO and EP. The results deduce that more involvement of managers in environmental concerns (i.e., environmental innovation-based strategies, clean production systems, ecofriendly products, green workplace environment, green engineering, and green chemistry, etc.), the greater the effect of entrepreneurship behavior toward caring and maintaining environmental performance (ecological and socioeconomic aspects).

The structural model's predictive relevance (Q2) is examined via the blindfolding procedures by (Geisser, 1975). When the $Q^{2}$ values are greater than zero, it predicts that the model is relevant, and when the Q2 values are near to 1, it indicates the greater the model is appropriate (Chin, 1998). Reading in Table 8 
shows the $Q^{2}$ values for GEO, GIP, and EP were $0.335,0.124$, and 0.528 , respectively. The result conjectures that the connectedness among these exogenous constructs (i.e., GEO, GIP, and EP) are more relevant, showing that GEO enables GIP practices to foster EP. Besides, $\mathrm{R}^{2}$ is further examined. Cohen (1988) noted that $R^{2}$ values above 0.26 are considered substantial, while values between 0.13 and 0.26 are considered moderate, whereas values between 0.02 and 0.13 are considered weak. The $R^{2}$ values of endogenous latent constructs in Table 8 are substantial for both GEO and EP and moderates GIP.

Table 8

Results of variance explained by constructs and predictive relevance of the research model.

\begin{tabular}{|lll|}
\hline Construct & Variance Explained $\left(\mathbf{R}^{2}\right)$ & Predictive Relevance $\left(Q^{2}\right)$ \\
\hline Green entrepreneurship orientation (GEO) & $26.4 \%$ & $33.5 \%$ \\
\hline Green innovation performance (GIP) & $14.6 \%$ & $12.4 \%$ \\
\hline Environmental performance (EP) & $47.8 \%$ & $52.8 \%$ \\
\hline
\end{tabular}

\section{Discussion}

Drawing upon the natural resource-based view (NRBV), this study aims to explain how environmental entrepreneurship can foster green practices and environmental performance. The study also aims to estimate GAC's coupled impact-GEO, EC-GEO, and MEC-GEO on both green innovation performance (GIP) and environmental performance. Advancing the NRBV lens, this research viewed GEO as a dynamic capability and tacit resources embedded within a green organizational culture to improve entrepreneurial ecosystem opportunities. This can be reached by improving environmental activities and protecting the natural environment (Hart \& Dowell, 2011). Therefore, GIP is acknowledged as a strategic solution to tackle these environmental activities. Hence, this study stands on dynamic capability theory and the NRBV in explaining the issue of environmental entrepreneurship, eco-innovation, and environmental performance (EP).

Advancing the NRBV perspective, the study examined GEO's impact on enhancing green practices and environmental performance. The finding indicated that GEO had a positive and significant direct impact on GIP and environmental performance. A few prior studies (Ebrahimi \& Mirbargkar, 2017; Engelen et al., 2014; Guo et al., 2020; Jiang et al., 2018) have addressed GEO's direct effect on GIP and EP in the presence of moderating and mediating factors. The finding of these studies matches our study findings. Whereas other studies (Saudi et al., 2019; Tang et al., 2018) findings do not match our study findings. This could result from different contexts, methodological and theoretical applied, and measurement of study variables. Additionally, the moderating impact of managerial environmental concerns on GEO and EP's relationship was also inspected. Further, the study tested the GAC's coupled impact-GEO, MEC-GEO, and EC-GEO on both GIP and EP. 
The findings of the study indicated that GAC had a positive and significant impact on GEO. This means that GAC facilitates GEO activities and helps to determine and capture eco-business opportunities. From the NRBV lens, GEO can be seen as dynamic capability and tacit resources aiming to catch entrepreneurial opportunities in line with responding to environmental responsibilities (Hart \& Dowell, 2011). GAC activities fall within the core strategies of GEO. Thus, the interaction impact would be high (Engelen et al., 2014). Several studies (Patel, 2019; Patel et al., 2015; Sciascia et al., 2014) found that GAC increases GEO's impact on different performance measures. Thus, first $\mathrm{H} 1$ a supported. Furthermore, the study found that when GEO activities coupled with GAC, the interaction impact resulted on GIP and EP increased, which suggesting that GEO motivated by the existence firms GAC in introducing valuable knowledge, skills, and practices to fulfill entrepreneurial environmental activities and business opportunities (Engelen et al., 2014).

Besides, most past studies have used GAC as an intermediary factor (mediator/moderator) (Engelen et al., 2014; Hughes et al., 2018; Sciascia et al., 2014) to enable GEO initiatives on green innovation practices and different performance measures. This study introduced GAC as a determinant of GEO to alert eco-business opportunities and foster environmental activities (Patel, 2019). Therefore, the more GAC engaged in GEO strategies (Sciascia et al., 2014), the more greener practices improved (Zhang et al., 2020), and thereby the more environmental activities enhanced (L. M. Pacheco et al., 2018). To conclude, GAC act as a bridge that protects GEO initiatives to exploit entrepreneurial opportunities. The second hypothesis, $\mathrm{H} 1 \mathrm{~b}$, is thereby supported.

Moreover, our study tested GAC's interaction impact-GEO on environmental performance, as stated in $\mathrm{H} 1 \mathrm{c}$. GEO is the practice and strategy looking to enhance environmental performance (Jiang et al., 2018; Pratono et al., 2019). GAC is the firm's an exploration and exploitation capabilities to restructure green business processes and products, green culture, and behavior, aiming to create an eco-friendly product and save energies to reduce environmental impacts (L. M. Pacheco et al., 2018). These environmental activities usually led to foster environmental performance and competitive advantage (Rehman et al., 2020). Thus, these activities with GEO initiatives would improve environmental performance and yield competitive advantages (Hart \& Dowell, 2011).

Furthermore, the results showed that MEC significantly and positively influenced GEO, and therefore, $\mathrm{H} 2 \mathrm{a}$ was maintained. From the NRBV lens, we can find strong theoretical justification about MEC's role in fostering environmental entrepreneurship (Hart \& Dowell, 2011; Rehman et al., 2020). The majority of past studies (Saudi et al., 2019; Tang et al., 2018; Xue et al., 2019) have mainly focused on MEC's role as an enabling factor to improve green innovation practices while ignored to establish and examine the role of MEC on GEO activities. This finding inferred that top managers acquired valuable awareness about environmental concerns. Thus, it resulted in supporting an entrepreneur's capabilities to explore environmental opportunities. MEC helps GEO by providing a clear image of environmental activities that should be improved and understanding external environmental opportunities and threats. This can be happening when managers are engaging in GEO activities. 
This research extends past studies (Saudi et al., 2019; Tang et al., 2018; Xue et al., 2019) by establishing the first empirical study linking and tested the direct impact of MEC on GEO and examined the indirect coupled impact of MEC-GEO on both GIP and EP. Managerial environmental concern mainly focused on exploiting those environmental activities and facilities to leverage GEO initiatives, which led to enhanced green practices and improved environmental performance. The natural resource-based view advocates that firms must respond to the external natural environment. Their environmental strategies must stand on three distinct criteria: addressing environmental activities to reduce pollution, product stewardship, and sustainable development (Hart \& Dowell, 2011; Rehman et al., 2020). Following this lens, it can be seen the practices and skills that must be acquired by managers in addressing environmental concerns. This study provides significant evidence by testing the theory and providing further support in the light of the entrepreneurial perspective about the need to explore external environmental activities. The close interaction of MEC with GEO resulted in a positive indirect impact on GIP and EP through GEO's mediation effect, and thereby $\mathrm{H} 2 \mathrm{~b}$ and $\mathrm{H} 2 \mathrm{c}$ were supported.

Besides, this study found that environmental cooperation (EC) significantly affects GEO. Thus, the hypothesized $\mathrm{H} 3 \mathrm{a}$ was supported. Also, findings show that $\mathrm{EC}$ had a significant positive indirect impact on GIP and EP through GEO's mediation effect. Consequently, the hypothesized H3b and H3c were supported. The implication of these results indicates that EC is a dynamic strategic capability for establishing relationships with external partners aimed at improving environmental activities. These networks led to restructuring business processes and applying green practices to overcome environmental concerns (Higgins \& Yarahmadi, 2014). These networks would result in a significant influence on mobilizing GEO strategies to address environmental opportunities. Applying the NRBV, this study's findings suggest that cooperation based on improving the external environment would help firm GEO achieve competitive advantage and superior environmental performance. Cooperation-based on environmental innovation fosters internal green practices (e.g., advancing production system, green engineering, clean technologies, and green workplace environment), eventually responding to environmental responsibilities (Higgins \& Yarahmadi, 2014; Kong et al., 2016).

Past studies found that EC's impact on GIP and firm performance is significant (Diabat et al., 2013; Higgins \& Yarahmadi, 2014; Perotti et al., 2012). These studies emphasized financial and non-financial measures whereas failed to address EC-GEO's association on GIP and environmental performance. Therefore, this study filled this practical and theoretical gap by linking and examining EC's direct impact on GEO and then testing the interaction impact of EC-GEO on both GIP and EP. By testing GEO's mediation impact on the relationship between EC, GIP, and EP, this research extends the NRBV knowledge body. The findings revealed that GEO interacts with MEC, and the resulted impact increases the capabilities of green practices and environmental performance. This means that the more MEC activities engaged and mobilized GEO strategies, the more environmental activities improved, leading to enhanced environmental performance. By doing so, this study tested the NRBV theory and provided extraordinary evidence about the need to care for the external natural environment in the light of environmental entrepreneurship. 
This finding is essential for entrepreneurs and management practices. This evidence demonstrates the importance of collaboration based on shared benefits that consider socioeconomic and ecological issues a primary concern. GEO seeking to extend businesses and respond to environmental problems must establish valuable networks with external parties to develop innovation capabilities that cover ecosystems issues more particular (Hájek \& Stejskal, 2018). Entrepreneurship collaboration based on environmental aspects such as governmental (regulations and tax preferences), private and public laboratories (R\&D to extend knowledge and practices), inter-organizational collaboration (suppliers of green raw materials, clean technologies, eco-friendly products techniques, and processes) considered as the driving force of GEO to improve GIP and environmental performance (Higgins \& Yarahmadi, 2014).

Moreover, the study findings show that MEC had a significant and direct positive effect on both EP. Consequently, $\mathrm{H} 7 \mathrm{a}$ was strengthened. This result reflected managers' critical role in taking environmental problems as primary tasks by incorporating these concerns into applied green strategies. It is also the first empirical study that theoretically linked and examined MEC's moderating role on the link between GEO and EP. The findings support the moderation hypothesis, which means that managers with sufficient knowledge and environmental awareness practices are involved more in environmental activities. They incorporate their tasks, efforts, and time to improve green practices [37] and upgrade firm strategies based on environmental situations and responsibilities. From the NRBV, it is clear to find that MEC strengthens the relationship between GEO and EP. MEC, mainly responsible for reducing environmental pollution and enhancing green practices, is expected to play a significant role in leveraging GEO strategies to achieve superior environmental performance.

\section{Conclusion}

Following the natural resource-based view, this study tested and provided significant evidence about the necessity to combine GAC, MEC, and EC with GEO initiatives to address GIP and EP. The study extends the body of the NRBV knowledge by providing the first empirical evidence to test the theory about the crucial impact of these three determining factors on facilitating GEO and advancing the performance of green innovation and environmental activities. The findings of this research are in line with the NRBV point of view. Referring to this theory, this research is the first empirical study that responds to the call to test the theory by examining the three distinct environmental strategies (1) reduction of pollution, (2) stewardship products, (3) sustainable development. These three interrelated distinct environmental strategies mainly focused on the core issue of environmental entrepreneurship and eco-innovation. Thus, this research had the chance to link these three concepts, namely GEO, GIP, and EP, in a single model to test the theory. This study identifies the role of firms GEO on improving green practices to fit and facilitate environmental activities. This would increase the chances to grasp eco-opportunities and enhance environmental performance. This study's primary purpose was to combine and examine GEO's strategic role in maintaining ecosystem performance by improving green practices.

\section{The implication for practice}


Dynamic capability theory recognizes GAC as the main driving force of GEO and GIP to facilitate the firm's capacity to transform and upgrade green knowledge resources to respond to environmental problems through deploying green practices to fit environmental concerns (Xue et al., 2019). The GAC enables GEO to understand and adopt up to date environmental changes by leveraging green practices (L. M. Pacheco et al., 2018). The more interaction between GAC activities in GEO, the more significant the improvement in eco-friendly products, eco-system sustainability, and green business growth. This study found that GAC, directly and indirectly, influences GEO, GIP, and EP, which means that GEO is encouraged by GAC's existence effect. It then successfully able to capture green opportunities, responsiveness flexibility to environmental restrictions and customer environmental awareness. Thus, leading firms to achieve superior environmental performance.

The natural resource-based view suggests that firms must consider three distinct environmental strategies to achieve competitive environmental advantages (ECA) (Hart, 1995; Hart \& Dowell, 2011). These advantages can be achieved when GEO is engaged in environmental activities to respond to the external natural environment (Rehman et al., 2020). Managerial environmental concern and environmental cooperation aimed at improving environmental activities and responsibilities of enhancing green innovation capabilities. This can be led to foster GEO alertness to explore eco-business

opportunities and improve environmental performance. Managers and entrepreneurs are advised to focus on environmental networks and improving organizational environmental awareness responding to tackle those activities that yielded environmental impacts.

\section{Theoretical implications and the novelty of the study}

This is the first empirical research that applied and responds to the NRBV lens by incorporating three distinct environmental strategies in understanding the interrelated impacts of the GEO, GIP, and EP in a single model. The DCT asserted that GEO is a proactive strategic decision to ensure the equilibrium between restrictions and opportunities in a dynamic environment (Teece, 2016). In contrast, GEO's primary responsibility is to improve environmental performance while continuously searching for ecoopportunities (Jiang et al., 2018). In contrast, the NRBV suggests that firms seeking to ensure competitive advantages must incorporate environmental strategies into their overall business strategy. The study argued that GEO is a dynamic capability that responds to the external natural environment while continuously addressing environmental opportunities. This research extends the body of knowledge of entrepreneurship and eco-innovation literature from the NRBV lens. Also, the study expands the NRBV lens by testing the theory in the body of entrepreneurship studies. This study addresses the strategic impact of environmental cooperation and managers' environmental awareness to foster green practices and environmental performance. Besides, this study also established the first theoretical model that addresses three distinct drivers of environmental strategies in a single model that were previously has been ignored. In doing so, this study's findings support the NRBV and extend the body of DCT by demonstrating the critical impact of the interrelationships highlighted in the research model under the umbrella of the NRBV. 


\section{Practical implications}

Firms that seek to sustain competitive advantages, especially those advantages that addressed environmental aspects, are more critical for individuals, markets, and government. The study's findings suggest that GEO must respond to the natural environment and responsible for environmental activities. Besides, to achieve superior environmental performance, firm GEO and managers must apply environmental strategies that emphasize three main complement strategies: reducing pollution, controlling eco-products, and ensuring sustainable development by minimizing energy use and waste. Furthermore, to track market green opportunities, firms should consider environmental problems as suggested by the NRBV. Given the strategic impact of absorptive capacity, managerial concerns, and environmental cooperation on GEO, GIP, and EP, it is essential for firms to comprehensively explore the implications of the finding provided by this study. Firms should track eco-friendly opportunities and exploit the existence of environmental opportunities enabled by GAC. GAC is the process of newly leveraging green practices responding to the external environment and GEO initiatives.

Moreover, networks and inter-organizational cooperation tends to be crucial to foster and facilitate environmental activities. Collaboration with partners helps to improve green practices and empower green organizational culture. Additionally, increased environmental awareness refers to managers' responsibilities to facilitate GEO strategies to achieve entrepreneurial eco-opportunities.

\section{Direction for future research}

This study focused on a single industry in China. Other industries operate under different regulations, political ties, and facilities. Thus, future research suggested expanding sampling beyond this context to have more generalized research findings. Besides, this study emphasizes a single industry as one of the major contributors to environmental problems. However, other industries have a considerable ecological impact, which subsequent motivating studies.

Additionally, this present research recommended that a longitudinal study be executed by tracking GEO, GIP, and EP's improvement progress across time. Besides, by conducting longitudinal analysis, the findings would provide substantial evidence about the relevance of the NRBV. Further, more empirical studies should explore the impact of individual, organizational, and institutional factors on GEO, GIP, and EP. Examining GEO and GIP's green workplace environment is vital since no published research has investigated this close link. It assumed it is one of the main driving forces for successfully deploying green practices among employees. Besides, applying this model within other contexts helps discover other factors associated with green innovation practices, GEO, and EP.

\section{Declarations}

\section{Authors Contributions}


Conceptualization: Lahcene Makhloufi; Methodology: Lahcene Makhloufi, Tang Meirun, Fateh Belaid, Noorulsadiqin Azbiya Yaacob; Formal analysis and investigation: Lahcene Makhloufi, Tang Meirun, Noorulsadiqin Azbiya Yaacob; Writing - original draft preparation: Lahcene Makhloufi; Writing - review and editing: Fateh Belaid, Noorulsadiqin Azbiya Yaacob; Resources: Tang Meirun; Supervision: Tang Meirun, Fateh Belaid.

\section{Competing Interests}

The authors have no conflicts of interest to declare that are relevant to the content of this article.

\section{Funding}

No funding was received to assist with the preparation of this manuscript.

\section{Ethical Approval}

Not applicable.

\section{Availability of data and materials}

Not applicable.

\section{Consent to Participate}

Not applicable.

\section{Consent to Publish}

Not applicable.

\section{References}

1. Aboelmaged, M., \& Hashem, G. (2019). Absorptive capacity and green innovation adoption in SMEs: The mediating effects of sustainable organisational capabilities. Journal of cleaner production, 220, 853-863.

2. Albino, V., Balice, A., \& Dangelico, R. M. (2009). Environmental strategies and green product development: an overview on sustainability-driven companies. Business Strategy and the Environment, 18(2), 83-96.

3. Albort-Morant, G., Leal-Millán, A., \& Cepeda-Carrión, G. (2016). The antecedents of green innovation performance: A model of learning and capabilities. Journal of Business Research, 69(11), 49124917.

4. Albort-Morant, G., Leal-Rodríguez, A. L., \& De Marchi, V. (2018). Absorptive capacity and relationship learning mechanisms as complementary drivers of green innovation performance. Journal of Knowledge Management. Vol. 22 No. 2, pp. 432-452. https://doi.org/10.1108/JKM-07-2017-0310. 
5. Anderson, A. R., Dodd, S. D., \& Jack, S. L. (2012). Entrepreneurship as connecting: some implications for theorising and practice. Management Decision. Vol. 50 No. 5, pp. 958-971. https://doi.org/10.1108/00251741211227708.

6. Arnold, M. G., \& Hockerts, K. (2011). The greening dutchman: Philips' process of green flagging to drive sustainable innovations. Business Strategy and the Environment, 20(6), 394-407.

7. Bai, Y., Song, S., Jiao, J., \& Yang, R. (2019). The impacts of government R\&D subsidies on green innovation: Evidence from Chinese energy-intensive firms. Journal of cleaner production, 233, 819829.

8. Bangwal, D., \& Tiwari, P. (2019). Workplace environment, employee satisfaction and intent to stay. International Journal of Contemporary Hospitality Management. Vol. 31 No. 1, pp. 268-284. https://doi.org/10.1108/IJCHM-04-2017-0230.

9. Berrone, P., Fosfuri, A., Gelabert, L., \& Gomez-Mejia, L. R. (2013). Necessity as the mother of 'green'inventions: Institutional pressures and environmental innovations. Strategic Management Journal, 34(8), 891-909.

10. Borghesi, S., Cainelli, G., \& Mazzanti, M. (2015). Linking emission trading to environmental innovation: evidence from the Italian manufacturing industry. Research Policy, 44(3), 669-683.

11. Cao, H., \& Chen, Z. (2019). The driving effect of internal and external environment on green innovation strategy-The moderating role of top management's environmental awareness. Nankai Business Review International. Vol. 10 No. 3, pp. 342-361. https://doi.org/10.1108/NBRI-05-20180028.

12. Cepeda-Carrion, I., Martelo-Landroguez, S., Leal-Rodríguez, A. L., \& Leal-Millán, A. (2017). Critical processes of knowledge management: An approach toward the creation of customer value. European Research on Management and Business Economics, 23(1), 1-7. https://doi.org/10.1016/j.iedeen.2016.03.001.

13. Chang, N.-J., \& Fong, C.-M. (2010). Green product quality, green corporate image, green customer satisfaction, and green customer loyalty. African journal of business management, 4(13), 2836-2844.

14. Chen, Y.-S. (2008). The driver of green innovation and green image-green core competence. Journal of business ethics, 81(3), 531-543.

15. Chen, Y.-S., \& Chang, C.-H. (2013). The determinants of green product development performance: Green dynamic capabilities, green transformational leadership, and green creativity. Journal of business ethics, 116(1), 107-119.

16. Chen, Y.-S., Lai, S.-B., \& Wen, C.-T. (2006). The influence of green innovation performance on corporate advantage in Taiwan. Journal of business ethics, 67(4), 331-339.

17. Chin, W. W. (1998). The partial least squares approach to structural equation modeling. Modern methods for business research, 295(2), 295-336.

18. Chuang, S.-P., \& Huang, S.-J. (2018). The effect of environmental corporate social responsibility on environmental performance and business competitiveness: The mediation of green information technology capital. Journal of Business Ethics, 150(4), 991-1009. 
19. Chuang, S.-P., \& Yang, C.-L. (2014). Key success factors when implementing a green-manufacturing system. Production Planning \& Control, 25(11), 923-937.

20. Cohen, J. (1988). Statistical power analysis for the behavioral sciences. 2nd. In: Hillsdale, NJ: erlbaum.

21. Corrocher, N., \& Solito, I. (2017). How do firms capture value from environmental innovations? An empirical analysis on European SMEs. Industry and Innovation, 24(5), 569-585.

22. Dangelico, R. M. (2015). Improving firm environmental performance and reputation: The role of employee green teams. Business Strategy and the Environment, 24(8), 735-749.

23. Dangelico, R. M., \& Pujari, D. (2010). Mainstreaming green product innovation: Why and how companies integrate environmental sustainability. Journal of business ethics, 95(3), 471-486.

24. Demirel, P., Li, Q. C., Rentocchini, F., \& Tamvada, J. P. (2019). Born to be green: new insights into the economics and management of green entrepreneurship. Small Business Economics, 52(4), 759-771.

25. Diabat, A., Khodaverdi, R., \& Olfat, L. (2013). An exploration of green supply chain practices and performances in an automotive industry. The International Journal of Advanced Manufacturing Technology, 68(1-4), 949-961.

26. Ebrahimi, P., \& Mirbargkar, S. M. (2017). Green entrepreneurship and green innovation for SME development in market turbulence. Eurasian Business Review, 7(2), 203-228.

27. El-Kassar, A.-N., \& Singh, S. K. (2019). Green innovation and organizational performance: the influence of big data and the moderating role of management commitment and HR practices. Technological Forecasting and Social Change, 144, 483-498.

28. Engelen, A., Kube, H., Schmidt, S., \& Flatten, T. C. (2014). Entrepreneurial orientation in turbulent environments: The moderating role of absorptive capacity. Research Policy, 43(8), 1353-1369.

29. Gast, J., Gundolf, K., \& Cesinger, B. (2017). Doing business in a green way: A systematic review of the ecological sustainability entrepreneurship literature and future research directions. Journal of cleaner production, 147, 44-56.

30. Geisser, S. (1975). A new approach to the fundamental problem of applied statistics. Sankhyā: The Indian Journal of Statistics, Series B, 385-397.

31. Gibbs, D., \& O'Neill, K. (2014). Rethinking sociotechnical transitions and green entrepreneurship: the potential for transformative change in the green building sector. Environment and Planning A, 46(5), 1088-1107.

32. Grimpe, C., \& Kaiser, U. (2010). Balancing internal and external knowledge acquisition: the gains and pains from R\&D outsourcing. Journal of management studies, 47(8), 1483-1509.

33. Guo, Y., Wang, L., \& Chen, Y. (2020). Green Entrepreneurial Orientation and Green Innovation: The Mediating Effect of Supply Chain Learning. SAGE Open, 10(1), 2158244019898798.

34. Hair, J. F., Ringle, C. M., \& Sarstedt, M. (2013). Partial least squares structural equation modeling: Rigorous applications, better results and higher acceptance. Long Range Planning, 46(1-2), 1-12. 
35. Hair Jr, J. F., Sarstedt, M., Hopkins, L., \& Kuppelwieser, V. G. (2014). Partial least squares structural equation modeling (PLS-SEM). European business review. Vol. 26 No. 2, pp. 106-121. https://doi.org/10.1108/EBR-10-2013-0128.

36. Hair Jr, J. F., Sarstedt, M., Ringle, C. M., \& Gudergan, S. P. (2017). Advanced issues in partial least squares structural equation modeling: saGe publications.USA.

37. Hájek, P., \& Stejskal, J. (2018). R\&D cooperation and knowledge spillover effects for sustainable business innovation in the chemical industry. Sustainability, 10(4), 1064.

38. Hart, S. L. (1995). A natural-resource-based view of the firm. Academy of management review, 20(4), 986-1014.

39. Hart, S. L., \& Dowell, G. (2011). Invited editorial: a natural-resource-based view of the firm: fifteen years after. Journal of management, 37(5), 1464-1479.

40. Henseler, J., \& Fassott, G. (2010). Testing moderating effects in PLS path models: An illustration of available procedures. In Handbook of partial least squares (pp. 713-735): Springer. Berlin, Heidelberg.

41. Henseler, J., Ringle, C. M., \& Sarstedt, M. (2015). A new criterion for assessing discriminant validity in variance-based structural equation modeling. Journal of the academy of marketing science, 43(1), 115-135.

42. Higgins, P. G., \& Yarahmadi, M. (2014). Cooperation as a Driver of Development and Diffusion of Environmental Innovation. Paper presented at the IFIP International Conference on Advances in Production Management Systems. (pp. 374-381). Springer, Berlin, Heidelberg.

43. Hughes, P., Hodgkinson, I. R., Hughes, M., \& Arshad, D. (2018). Explaining the entrepreneurial orientation-performance relationship in emerging economies: The intermediate roles of absorptive capacity and improvisation. Asia Pacific Journal of Management, 35(4), 1025-1053.

44. Ibarra-Cisneros, M.-A., \& Hernandez-Perlines, F. (2019). Entrepreneurial orientation, absorptive capacity and business performance in SMEs. Measuring Business Excellence. Vol. 24 No. 4, pp. $417-$ 429. https://doi.org/10.1108/MBE-09-2019-0091.

45. Israel, G. D. (2003). Determining Sample Size. Program Evaluation and Organizational Development, IFAS, University of Florida. PEOD-5. In: October.

46. Jack, S., Moult, S., Anderson, A. R., \& Dodd, S. (2010). An entrepreneurial network evolving: Patterns of change. International small business journal, 28(4), 315-337.

47. Jang, Y. J., Zheng, T., \& Bosselman, R. (2017). Top managers' environmental values, leadership, and stakeholder engagement in promoting environmental sustainability in the restaurant industry. International Journal of Hospitality Management, 63, 101-111.

48. Jiang, W., Chai, H., Shao, J., \& Feng, T. (2018). Green entrepreneurial orientation for enhancing firm performance: A dynamic capability perspective. Journal of cleaner production, 198, 1311-1323.

49. Kasayanond, A., Umam, R., \& Jermsittiparsert, K. (2019). Environmental sustainability and its growth in Malaysia by elaborating the green economy and environmental efficiency. International Journal of Energy Economics and Policy, 9(5), 465. 
50. Kirkwood, J., \& Walton, S. (2014). How green is green? Ecopreneurs balancing environmental concerns and business goals. Australasian Journal of Environmental Management, 21(1), 37-51.

51. Kline, E., Wilson, C., Ereshefsky, S., Tsuji, T., Schiffman, J., Pitts, S., \& Reeves, G. (2012). Convergent and discriminant validity of attenuated psychosis screening tools. Schizophrenia research, 134(1), 49-53.

52. Kobarg, S., Stumpf-Wollersheim, J., Schlägel, C., \& Welpe, I. M. (2020). Green together? The effects of companies' innovation collaboration with different partner types on ecological process and product innovation. Industry and Innovation, 1-38. DOI: 10.1080/13662716.2020.1713733.

53. Kock, N. (2015). Common method bias in PLS-SEM: A full collinearity assessment approach. International Journal of e-Collaboration (IJeC), 11(4), 1-10.

54. Kong, T., Feng, T., \& Ye, C. (2016). Advanced manufacturing technologies and green innovation: The role of internal environmental collaboration. Sustainability, 8(10), 1056.

55. Kraus, S., Rehman, S. U., \& García, F. J. S. (2020). Corporate social responsibility and environmental performance: The mediating role of environmental strategy and green innovation. Technological Forecasting and Social Change, 160, 120262.

56. Krejcie, R. V., \& Morgan, D. W. (1970). Determining sample size for research activities. Educational and psychological measurement, 30(3), 607-610.

57. Li, Y. (2014). Environmental innovation practices and performance: moderating effect of resource commitment. Journal of Cleaner Production, 66, 450-458.

58. Matus, K. J., Xiao, X., \& Zimmerman, J. B. (2012). Green chemistry and green engineering in China: drivers, policies and barriers to innovation. Journal of cleaner production, 32, 193-203.

59. Melander, L. (2017). Achieving sustainable development by collaborating in green product innovation. Business Strategy and the Environment, 26(8), 1095-1109.

60. Nasrollahi, M., Fathi, M. R., \& Hassani, N. S. (2020). Eco-innovation and cleaner production as sustainable competitive advantage antecedents: the mediating role of green performance. International Journal of Business Innovation and Research, 22(3), 388-407.

61. Ng, D. W. (2007). A modern resource based approach to unrelated diversification. Journal of Management Studies, 44(8), 1481-1502.

62. Nordin, R., \& Hassan, R. A. (2019). The Role of Opportunities for Green Entrepreneurship Towards Investigating the Practice of Green Entrepreneurship among SMEs in Malaysia. Review of Integrative Business and Economics Research, 8, 99-116.

63. Pacheco, D. F., Dean, T. J., \& Payne, D. S. (2010). Escaping the green prison: Entrepreneurship and the creation of opportunities for sustainable development. Journal of business venturing, 25(5), 464-480.

64. Pacheco, L. M., Alves, M. F. R., \& Liboni, L. B. (2018). Green absorptive capacity: A mediationmoderation model of knowledge for innovation. Business Strategy and the Environment, 27(8), 15021513. 
65. Pallant, J. (2011). SPSS Survival manual: a step by step guide to data analysis using SPSS. Crows Nest. New South Wales: Allen \& Unwin.

66. Patel, P. C. (2019). Opportunity related absorptive capacity and entrepreneurial alertness. International Entrepreneurship and Management Journal, 15(1), 63-73.

67. Patel, P. C., Kohtamäki, M., Parida, V., \& Wincent, J. (2015). Entrepreneurial orientation-asexperimentation and firm performance: The enabling role of absorptive capacity. Strategic Management Journal, 36(11), 1739-1749.

68. Perotti, S., Zorzini, M., Cagno, E., \& Micheli, G. J. (2012). Green supply chain practices and company performance: the case of 3PLs in Italy. International Journal of Physical Distribution \& Logistics Management. Vol. 42 No. 7, pp. 640-672. https://doi.org/10.1108/09600031211258138.

69. Pratono, A. H., Darmasetiawan, N. K., Yudiarso, A., \& Jeong, B. G. (2019). Achieving sustainable competitive advantage through green entrepreneurial orientation and market orientation. The Bottom Line. Vol. 32 No. 1, pp. 2-15. https://doi.org/10.1108/BL-10-2018-0045.

70. Preacher, K. J., \& Hayes, A. F. (2004). SPSS and SAS procedures for estimating indirect effects in simple mediation models. Behavior research methods, instruments, \& computers, 36(4), 717-731.

71. Preacher, K. J., \& Hayes, A. F. (2008). Asymptotic and resampling strategies for assessing and comparing indirect effects in multiple mediator models. Behavior research methods, 40(3), 879-891.

72. Raza, A., \& Murad, H. S. (2014). Learning new management viewpoints: Re-contextualizing strategic leadership in global and regional context. Vol. 7 No. (1), pp. 103-109. http://hdl.handle.net/123456789/1452.

73. Rehman, S. U., Kraus, S., Shah, S. A., Khanin, D., \& Mahto, R. V. (2020). Analyzing the relationship between green innovation and environmental performance in large manufacturing firms. Technological Forecasting and Social Change, 120481.

74. Saudi, M. H. M., Sinaga, G., \& Zainudin, Z. (2019). The effect of green innovation in influencing sustainable performance: moderating role of managerial environmental concern. Int J Sup Chain Mgt, 8, 303.

75. Saunila, M., Ukko, J., \& Rantala, T. (2018). Sustainability as a driver of green innovation investment and exploitation. Journal of cleaner production, 179, 631-641.

76. Schaefer, K., Corner, P. D., \& Kearins, K. (2015). Social, environmental and sustainable entrepreneurship research: what is needed for sustainability-as-flourishing? Organization \& environment, 28(4), 394-413.

77. Sciascia, S., D'oria, L., Bruni, M., \& Larraneta, B. (2014). Entrepreneurial Orientation in low-and medium-tech industries: The need for Absorptive Capacity to increase performance. European management journal, 32(5), 761-769.

78. Song, M., Fisher, R., \& Kwoh, Y. (2019). Technological challenges of green innovation and sustainable resource management with large scale data. Technological Forecasting and Social Change, 144, 361368. 
79. Sun, H., Edziah, B. K., Sun, C., \& Kporsu, A. K. (2019). Institutional quality, green innovation and energy efficiency. Energy policy, 135, 111002.

80. Sun, L.-y., Miao, C.-I., \& Yang, L. (2017). Ecological-economic efficiency evaluation of green technology innovation in strategic emerging industries based on entropy weighted TOPSIS method. Ecological indicators, 73, 554-558.

81. Tang, M., Walsh, G., Lerner, D., Fitza, M. A., \& Li, Q. (2018). Green innovation, managerial concern and firm performance: An empirical study. Business Strategy and the Environment, 27(1), 39-51.

82. Teece, D. J. (2014). The foundations of enterprise performance: Dynamic and ordinary capabilities in an (economic) theory of firms. Academy of management perspectives, 28(4), 328-352.

83. Teece, D. J. (2016). Dynamic capabilities and entrepreneurial management in large organizations: Toward a theory of the (entrepreneurial) firm. European Economic Review, 86, 202-216.

84. Triguero, A., Moreno-Mondéjar, L., \& Davia, M. A. (2013). Drivers of different types of eco-innovation in European SMEs. Ecological economics, 92, 25-33.

85. Ullah, S., \& Qaiser Danish, R. (2020). The Impact of Green Entrepreneurial Orientation on Firm Performance through Green Innovation: The Moderating Role of Strategic Green Marketing Orientation. European Online Journal of Natural and Social Sciences, 9(2), pp. 306-317.

86. Vachon, S., \& Klassen, R. D. (2006). Extending green practices across the supply chain: the impact of upstream and downstream integration. International Journal of Operations \& Production Management, 26(7), 795-821.

87. Van Beers, C., \& Zand, F. (2014). R\&D cooperation, partner diversity, and innovation performance: an empirical analysis. Journal of Product Innovation Management, 31(2), 292-312.

88. Van Doorn, S., Heyden, M., Tröster, C., \& Volberda, H. (2015). Entrepreneurial orientation and performance: Investigating local requirements for entrepreneurial decision-making. In Cognition and Strategy. Emerald Group Publishing Limited.Vol (32), pp. 211-239.

89. Van Doorn, S., Heyden, M. L., \& Volberda, H. W. (2017). Enhancing entrepreneurial orientation in dynamic environments: The interplay between top management team advice-seeking and absorptive capacity. Long Range Planning, 50(2), 134-144.

90. Van Doorn, S., Jansen, J. J., Van den Bosch, F. A., \& Volberda, H. W. (2013). Entrepreneurial orientation and firm performance: Drawing attention to the senior team. Journal of Product Innovation Management, 30(5), 821-836.

91. Wagner, M., \& Llerena, P. (2011). Eco-innovation through integration, regulation and cooperation: comparative insights from case studies in three manufacturing sectors. Industry and Innovation, 18(8), 747-764.

92. Wang, Y., Liu, J., Hansson, L., Zhang, K., \& Wang, R. (2011). Implementing stricter environmental regulation to enhance eco-efficiency and sustainability: a case study of Shandong Province's pulp and paper industry, China. Journal of cleaner production, 19(4), 303-310.

93. Weber, B., \& Heidenreich, S. (2018). When and with whom to cooperate? Investigating effects of cooperation stage and type on innovation capabilities and success. Long Range Planning, 51(2), 
334-350.

94. Westman, C., \& Thorgren, S. (2016). Partner conflicts in international joint ventures: A minority owner perspective. Journal of International Management, 22(2), 168-185.

95. Woldesenbet, K., Ram, M., \& Jones, T. (2012). Supplying large firms: The role of entrepreneurial and dynamic capabilities in small businesses. International Small Business Journal, 30(5), 493-512.

96. Xue, M., Boadu, F., \& Xie, Y. (2019). The Penetration of Green Innovation on Firm Performance: Effects of Absorptive Capacity and Managerial Environmental Concern. Sustainability, 11(9), 2455.

97. Younis, H., Sundarakani, B., \& Vel, P. (2016). The impact of implementing green supply chain management practices on corporate performance. Competitiveness Review. Vol. 26 No. 3, pp. 216245. https://doi.org/10.1108/CR-04-2015-0024.

98. Yunus, E. N., \& Michalisin, M. D. (2016). Sustained competitive advantage through green supply chain management practices: a natural-resource-based view approach. International Journal of Services and Operations Management, 25(2), 135-154.

99. Zahra, S. A., Filatotchev, I., \& Wright, M. (2009). How do threshold firms sustain corporate entrepreneurship? The role of boards and absorptive capacity. Journal of business venturing, 24(3), 248-260.

100. Zameer, H., Wang, Y., \& Yasmeen, H. (2020). Reinforcing green competitive advantage through green production, creativity and green brand image: implications for cleaner production in China. Journal of cleaner production, 247, 119119.

101. Zhang, J., Liang, G., Feng, T., Yuan, C., \& Jiang, W. (2020). Green innovation to respond to environmental regulation: How external knowledge adoption and green absorptive capacity matter? Business Strategy and the Environment, 29(1), 39-53.

\section{Figures}




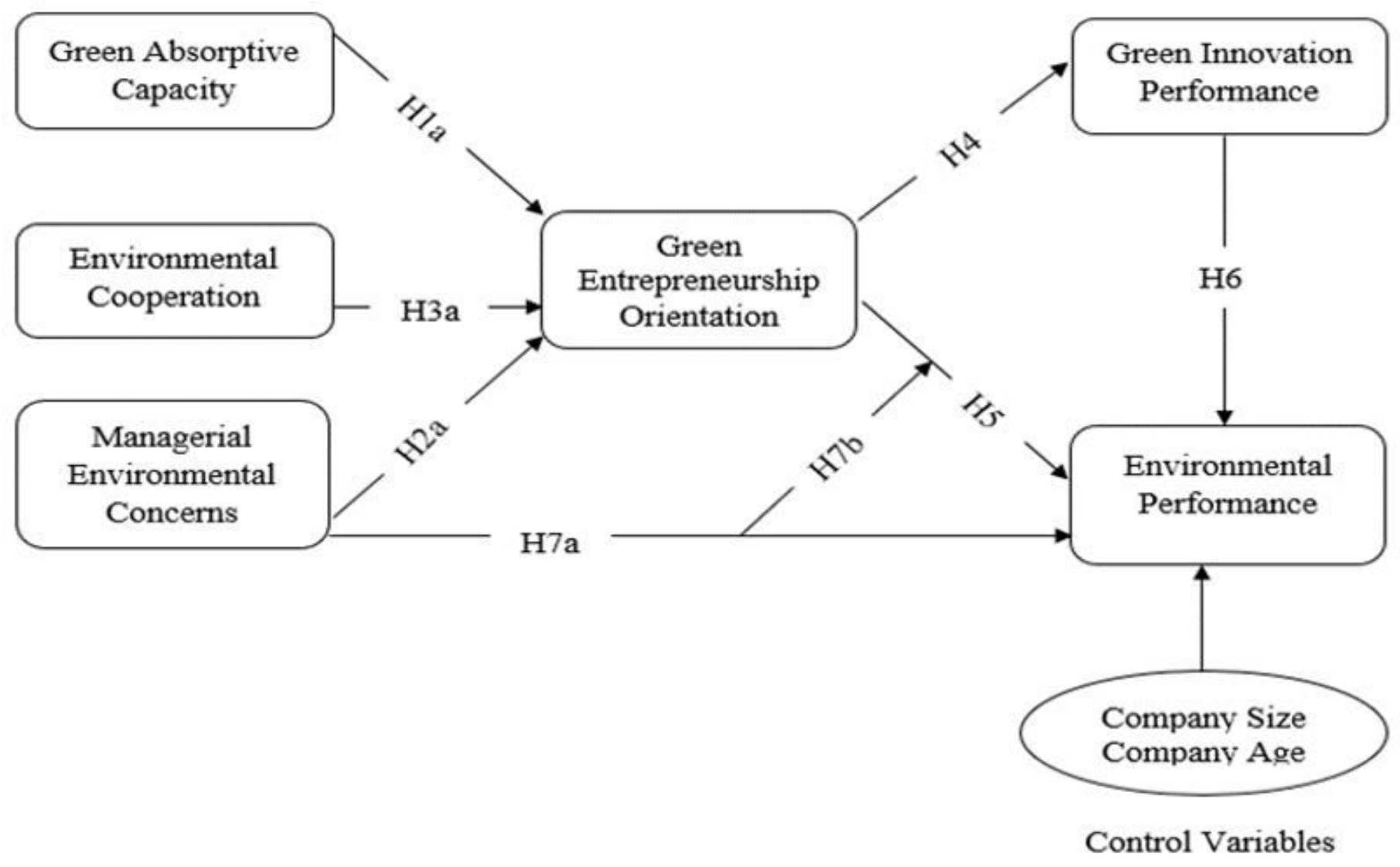

Figure 1

Proposed Theoretical Framework. 


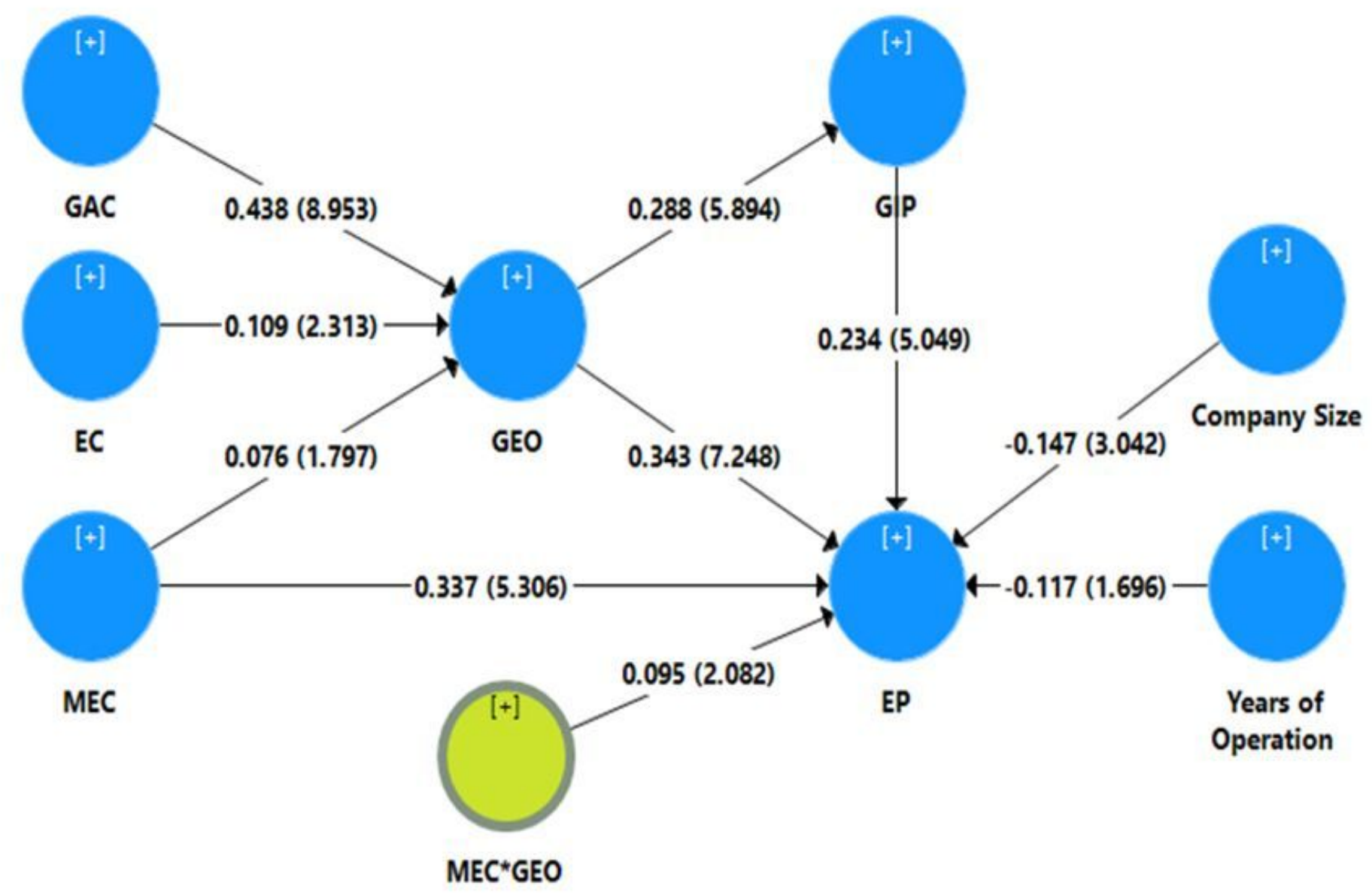

Figure 2

Results of Structural Model. Note: GAC: Green absorptive capacity, EC: Environmental cooperation, MEC: Managerial environmental concern, GIP: Green innovation performance, GEO, Green entrepreneurship orientation, EP: Environmental performance. 


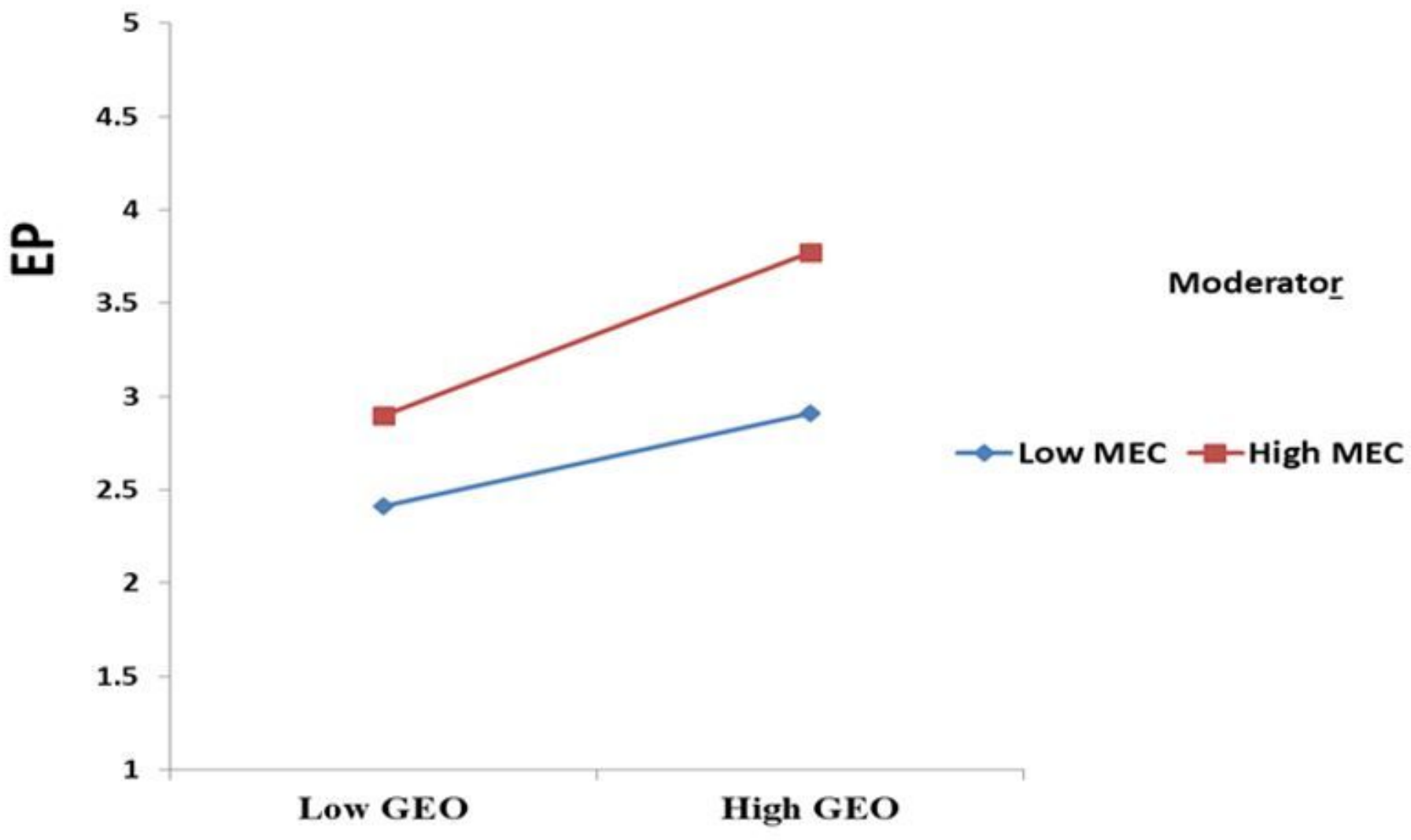

\section{Figure 3}

Moderation effect. Note: EP: environmental performance, GEO: green entrepreneurship orientation, MEC: managerial environmental concern. 